\title{
The 12th century seismic paroxysm in the Middle East: a historical perspective
}

\author{
Nicholas N. Ambraseys \\ Department of Civil Engineering, Imperial College, London, U.K.
}

\begin{abstract}
The Dead Sea Fault and its junction with the southern segment of the East Anatolian fault zone, despite their high tectonic activity have been relatively quiescent in the last two centuries. Historical evidence, however, shows that in the 12th century these faults ruptured producing the large earthquakes of 1114, 1138, 1157 and 1170. This paroxysm occurred during one of the best-documented periods for which we have both Occidental and Arab chronicles, and shows that the activity of the 20th century, which is low, is definitely not a reliable guide to the activity over a longer period. The article is written for this Workshop Proceedings with the archaeoseismologist, and in particular with the seismophile historian in mind. It aims primarily at putting on record what is known about the seismicity of the region in the 12th century, describe the problems associated with the interpretation of macroseismic data, their limitations and misuse, and assess their completeness, rather than answer in detail questions regarding the tectonics and seismic hazard of the region, which will be dealt with elsewhere on a regional basis.
\end{abstract}

Key words Middle East - 12th century - historical earthquakes

\section{Introduction}

The purpose of this article is to present the retrieval and uniform processing of information for the study of the 12th century seismicity of the region, which is defined by $33^{\circ}$ to $38^{\circ} \mathrm{N}$ and $35^{\circ}$ to $39^{\circ} \mathrm{E}$, and includes Southeastern Turkey, Syria and Lebanon. This information may be used for the assessment of the location, and size of 12 th century earthquakes and their association with regional tectonics. Results from historical studies like this will be of value to the earth scientist and engineer alike, only when descrip-

Mailing address: Dr. Nicholas N. Ambraseys, Department of Civil Engineering, Imperial College, London SW7 2AZ, U.K.; e-mail: n.ambraseys@ imperial.ac.uk tive effects derived from historical sources can be reliably quantified.

The assessment of an historical earthquake requires the documentary information to be reviewed with reference to the environmental conditions and historical factors that have influenced the reporting of the event. In evaluating the evidence for individual earthquakes and the completeness of information as a whole, attention must be given to exaggeration, the role of population distribution, communications and availability of historical documents. The significance of negative evidence and lack of data also need to be considered.

\section{Environmental conditions}

Tectonic features - The dominant tectonic feature of the Levant responsible for destructive earthquakes is the Dead Sea fault system. It is a zone of left-lateral strike-slip running from the 
Gulf of Aqaba in the south to join the East Anatolian fault zone near Maras in SE Turkey (fig. 1), accommodating about $8-10 \mathrm{~mm} / \mathrm{yr}$ of slip between Arabia and Africa.

The East Anatolian fault zone is also predominantly left-lateral strike-slip in nature, but the faulting within it is less continuous, less localized and more varied in nature than in the

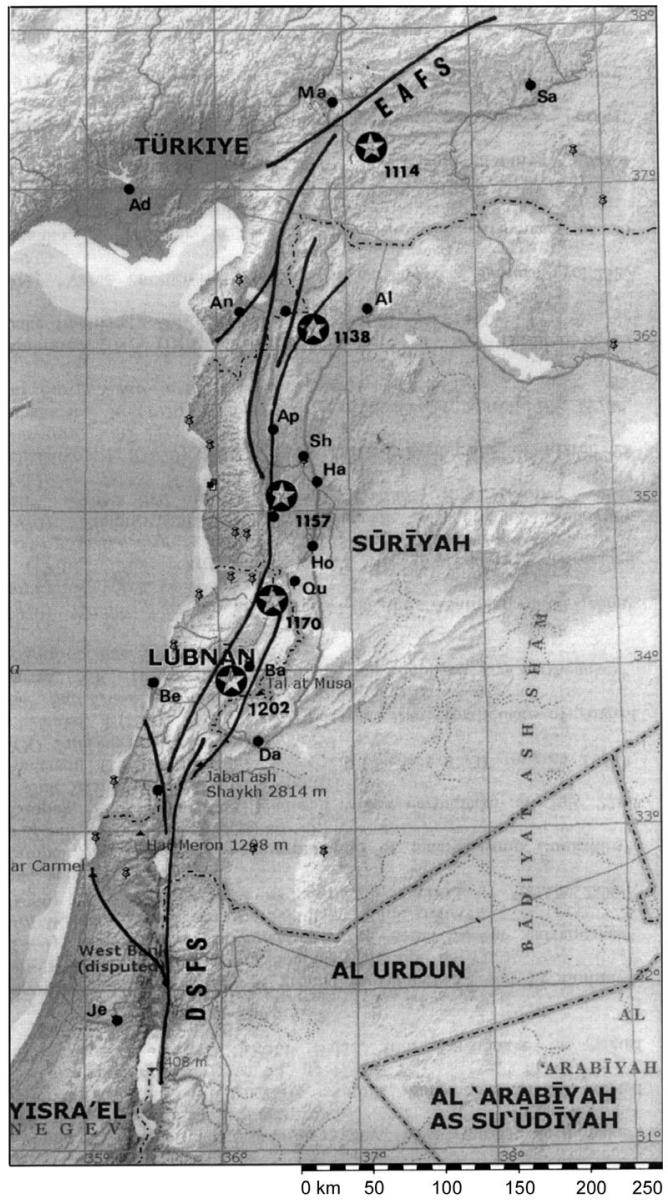

Fig. 1. The dominant tectonic feature of the Levant. DSFS - Dead Sea fault system; EAFS - East Anatolian fault zone. Open stars show the general location of the epicentral region of the earthquakes investigated. The location of the 1202 earthquake comes from a separate study (Ambraseys and Melville, 1988).
North Anatolian fault zone. Its junction with the Dead Sea Fault occurs in the region between Maras, Adana and Aleppo forming a poorly understood broad zone of diffused seismicity.

Seismicity in this region is restricted to the upper $10-20 \mathrm{~km}$ of the continental crust while the lower crust is generally aseismic. Despite their high tectonic activity the Dead Sea Fault and its junction with southern segment of the East Anatolian fault zone have been quiet in the last two centuries, though they have produced many large earthquake in the past such as those discussed in this article.

Geographic factors - The region consists of large tracts with different geologic site conditions; from predominantly soft rock on the mountains, to loose saturated sands and silts in the basins, areas responsible for foundation and slope failures even under normal conditions. These areas, such as in the Adana plains, the Amik Golu, Nahr al 'Asi (Orontes) valleys and throughout the Mesopotamian plains, always tend to enhance damage and respond strongly to large distant earthquakes. Liquefaction and damage to structures due to foundation failure are not indicators of high earthquake intensity.

Building stock - The vulnerability of the building stock in the region varies enormously. In the 12th century, in towns, and to a lesser extent throughout rural areas, better-built constructions were of stone, laid predominantly in clay mortar, and plastered. However, in most cases, heavy damage to buildings was due to both poor construction and lack of repairs, while for forts and castles built on hilltops or on sloping ground, damage was chiefly due to differential settlements, overturning and incipient sliding of their foundations.

In villages rural houses were built chiefly of sun-dried mud and adobe with roofs of tamped earth, which becomes particularly heavy during the rainy season. On the hills and mountains stone was used for more substantial houses, few of them two storey high, built on sloping ground or on hilltops.

Population density - We have no 12th century figures for the number of people living in 
the region. For the early 16th century Barkan (1958) estimates a total population of about 600000 , of which 67000 lived in Aleppo and 57000 in Damascus.

\section{Historical factors}

The earthquakes occurred in what is today Lebanon, Syria and southeastern Turkey, at a time of continuing conflict during the successive military and religious Crusading expeditions organised in Western Europe against the Muslims which intended to take back and defend against Islam the Holy Places of Palestine and Syria. For a background of the history of the region during that period, see Röhricht (1898), Runciman (1952) and Maalouf (1983).

It is important to note, therefore, that continuing warfare and earthquakes before and throughout the 12th century, in both Muslim and Christian territories, had progressively enhanced the vulnerability of hastily repaired fortified towns, castles, and houses, much of the damage caused by earthquakes reflecting the cumulative effects of both deliberate and earthquake damage. In assessing intensities, this is an important consideration for which allowance must be made.

\section{Sources of information}

One of the objectives is to provide a uniform account of seismicity from the assessment of original sources of information. Our area has a well-documented history preserved in a variety of sources including mediaeval Arabic and Occidental chronicles. These are supplemented by Syriac, Byzantine and Jewish sources and also by archaeological studies. In contrast with other parts of the world, for which there is unpublished information awaiting retrieval from archives and repositories, for our region many primary sources are well known, most of them published.

Thanks to Röhricht's work, and to the work of many others such as Berchem and Fatio (1913), almost all primary sources of 12th century earthquakes in Syria are easy to locate. Al- so a corpus of texts from Arabic sources of material on the seismicity of the Arab region can be found in Taher $(1979,1996)$. Although these work are not without blemishes regarding date conversion and amalgamation of events, their great value is in the unexpurgated data of the Arabic texts that they provide. An interesting summary of the effect of earthquake and plague in Arabic sources is given by Kremer (1880).

So, there is no real difficulty in knowing where to look for useful information. The real difficulty is to improve on the factual interpretation of this material by systematically reading all the relevant texts, in their original language if possible, with the aid of reliable commentaries and other pertinent works. Historiographic and linguistic problems are addressed only when they have a bearing on the scientific understanding of the earthquake in question.

There is little additional evidence to help assess damage or intensities by archaeological reports. Archaeological studies on the whole use documentary evidence of earthquakes to support the chronology and identification of repair or reconstruction phases at castles and public buildings, rather than archaeological evidence of rebuilding to indicate the extent of earthquake damage.

\section{Discussion}

\subsection{Reliability of source material}

Almost all of the 12th century and later documents give an apocalyptic account of earthquake effects and describe the ensuing human suffering in graphic detail, most of this in a standard disaster language. Other sources give a muddled picture, but often few do have interesting details. Although this is not sufficient to throw these accounts in doubt, it does give different interpretations of the facts, which often lead modern writers to assign grossly inflated intensities, not only to Middle Eastern earthquakes but also Greek and particularly Italian.

Natural exaggeration in historical sources is well recognised and not difficult to detect (Berchem and Fatio, 1913). The authenticity of 
the source, the style of its narrative, internal evidence in the account and experience gained from processing local information, all combine to permit a realistic assessment of the seriousness of the situation. It is important to keep an open mind about information, which, though beyond one's experience, is not impossible.

Descriptions of the 1170 earthquake such as: $« . .$. the earthquake razed to the ground a swathe of most ancient and well-fortified cities throughout the whole Orient, burying their inhabitants» ... «There was no place, undamaged even as far as the ends of the earth, or that it was the greatest and more violent shock than any, which were said to have happened in the memory of men», imply a catastrophic event of an unprecedented magnitude. Yet the same authors go on to say that after the earthquake, people were staying outside their houses, that they took refuge in churches and mosques or that it took them only three weeks to repair the damage. Allowing exaggeration of damage in early sources to influence the assessment of destructiveness of earthquakes has lead modern writers to assign grossly inflated intensities.

With few exceptions all texts are rhetorical and self-consciously literary in their style, and therefore exaggerate the earthquake's effects, although in terms of content they closely resemble the briefer and plainer texts given by few contemporary writers.

The reliability of the sources varies considerably. For instance, Runciman describes Matthew of Edessa as «naïve», and remarks «much of his information about the Crusade must have been derived from some ignorant Frankish soldier; but about events in his native city and its neighbourhood he was very fully informed». Runciman also notes Ibn al-Athir's chronological deficiencies and his tendency to transform his sources' accounts and dates after his own prejudices (Runciman, 1951, 1952).

It is unusual for sources to note that earthquakes caused disasters in the rural areas as well as the cities. Most sources tend to mention the effects of earthquakes only on cities or entire regions. Also casualty figures are difficult to check and are anyway not necessary indicative of the intensity of an earthquake.

\subsection{Location and timing of earthquakes}

Because of the emphasis on effects in major urban centres, reported figures depended to a large extent on population distribution and density. Even approximate figures, such as those given for the larger 12th century earthquakes, seem to be a rough popular estimate.

Duplication of earthquakes also has been a problem, particularly with modern writers. Several systems have been used to date earthquake, notably the Muslim (a.H.), Seleucid (Sel.), Armenian (Ar.), and the Julian (Old Style) calendars. Details of these may be found in Grumel (1958) and Cattenoz (1961). A difficulty can arise from the fact that the Muslim and the Christian day do not precisely correspond. Whereas the Christian day is reckoned from midnight to midnight, the Muslim day begins at sunset, time being reckoned in twelve-hourly periods from 6 p.m. For this reason Muslims likewise reckon the days of the week from sunset to sunset, and what to the Muslim in Sunday evening is to the Christian still Saturday evening. In dating earthquakes if these differences are overlooked, or the time of the day is not known, an incorrect date can be put on an event. This is Willis's mistake - see below -, which lay in failing to convert dates in the Muslim calendar, with the result that a considerable number of events were dated many years too early.

\subsection{Assessment of intensity}

For the purpose of assessing intensity and reducing subjectivity it is important to distinguish between damage caused by vibrational, dynamic or inertia loading, and damage caused by indirect, secondary effects, such as foundation spreading, liquefaction, slides, rock falls and aftershocks. Liquefaction will cause damage from excessive differential settlement rather than from ground shaking. This kind of built environment makes it difficult to assess damage and apply damage criteria inherent in modern Intensity scales.

Another factor to be borne in mind is the way in which earthquakes and earthquake damage was perceived and reported in the sources. The 
systematic use of terms such as «strong», «frightening», «great», «large» or «not seen before» is merely repeating or adding to what their various sources wrote, rather than applying a uniform reassessment of their own, and one author's strong is another author's great. «Large» may mean different things in different contexts: a large earthquake in Britain is a different matter from a large earthquake in Turkey. It is the rule rather than exception of the same shock or degree of damage being given in conflicting ways in the chronicles, and these terms alone cannot be used to assess intensities of earthquakes in the Middle Ages, not only in the Middle East but also in Europe. Early intensity reports are typically amplified by the high vulnerability building stock and by exaggerated reporting that conspire towards the levels where 20th century scales saturate.

Mortality caused by earthquakes depends directly on the vulnerability of the built environment and on population density and only indirectly on epicentral distance. Major earthquakes may be expected to kill more than 10 percent of the population in the epicentral area. Where the housing stock consists primarily of weak, heavywalled structures, the death toll will be much higher.

Other factors, such as the level of occupancy of dwellings may affect this percentage so that much larger life loss should be expected if the earthquake occurred at night, in the winter. Obviously, loss of life is not a criterion, and alone it cannot be used to assess intensity.

Some of the historical, and modern earthquakes originating from the region are felt at abnormally great distances to the south and to the east than away from the mainland to the north and west. This preferential distribution is due to the enhancing effect the Nile Delta and Nile of alluvial valleys, and also due to the low attenuation of seismic waves across the Arabian shield in these directions rather than due to any other less obvious causes (Ambraseys, 2001).

\subsection{Existing earthquake catalogues}

Numerous 20th century catalogues of historical Middle Eastern earthquakes have appeared and the rate at which they are produced in the 21 st century has increased, most of them fatally flawed. The intention towards their authors, particularly seismophile historians, is not vindictive; precisely because they are authoritative as well as recent works, but the problems they contain are the most extensive and pervasive, and therefore most need to be exposed (Ambraseys et al., 2004). For instance Willis's remarkable error that was noticed by the author himself (Willis, 1928, 1933) but not before erroneous entries from his list had found their way into other catalogues (Sieberg, 1932a,b). While Willis is therefore rightly treated with caution, the same misgiving is not applied to Sieberg and other later authors (Sieberg, 1932a,b). Sieberg's work is prominent among those used in the most recent authoritative catalogue of Middle East earthquakes by BenMenahem (1979). Another example is the results of Taher's research, which were presented by Poirier and Taher (1980). Their catalogue unfortunately passes on, and even adds to, the inaccuracies in the original work.

This highlights the interesting problem of how to achieve consistency and homogeneity in a catalogue relying on very diverse material, which ideally needs a specialist in each relevant field, and without reading through the full texts from sources written in different languages.

\section{Conclusions}

The ultimate purpose underlying the quantitative assessment of earthquake hazard using historical data is to identify active tectonic elements and to obtain an estimate of the regional long-term seismic exposure. The means to obtain this estimate is the identification of sites, which have been associated with large historical events and the assessment of their magnitude (see Ambraseys and Jackson, 1998).

From fig. 1 we notice that the seismic activity in the 12 th century occurred in a remarkable series of earthquakes that moved successively from north to south along the East Anatolian and Dead Sea fault systems.

The 1114 earthquake and its foreshocks are clearly associated with the East Anatolian fault zone, probably of $M>7$, the shock occurring 
southwest of the earthquake $(M=7.1)$ of 2 March 1893 (Ambraseys, 1989). The next event of 1138 occurred on the Dead Sea fault system, south of its junction with the East Anatolian Fault System, perhaps of $M<7$. This was followed in 1151 by an ill-defined activity in the region of Bosra and the Hauran in SE Syria, probably associated with the Palmyride fold belt. Next we have what seems to be a strong foreshock in 13 July 1157 in the region of Hama, which was followed on 12 August 1157 by the large Hama earthquake $(M>>7)$ that must be associated with the bent of the fault system. This is common with all major continental strike-slip faults; the Dead Sea fault system is likely to be segmented, with rupture in individual earthquakes limited in length by structural discontinuities or bends. Finally the large earthquake of 29 June 1170, probably of $M>>7$, completed the activity in the 12th century, but the paroxysm continued into the next century with the large shock of 1202 (Ambraseys and Melville, 1988) which extended the activity even further south on the straight Yammouneh fault segment of the main left-lateral fault system, which runs NNE-SSW for about $150 \mathrm{~m}$ and is thus oblique to the overall AfricaArabia motion.

It is likely that in this area the deformation is probably distributed over more than one fault, and may even be separated into its strikeslip and thrust component as is seen elsewhere in regions of oblique convergence. A manifestation of this distributed deformation may be the large earthquake $(M>7)$ of 1837 in southern Lebanon, which appears not to have occurred on the Yammouneh Fault, and may have been on the Roum Fault instead (Ambraseys, 1997). The size of these events is not different from better-documented large earthquakes in the region (Ambraseys and Melville, 1988; Ambraseys and Barazangi, 1989).

It is evident from the quiescence of the 20th century compared with the large earthquakes of historical times that the main Dead Sea fault system itself remains locked between slip events in major earthquakes.

Oddly enough, despite the relatively large magnitude of these earthquakes and of their clear association with active faults, there is no mention in the sources about ground deformations that could be of tectonic origin. The only allusion we find is in the description of earthquake of 1170 in which it is said that deep fissures opened in the ground in the mountains overlooking Baalbek.

One of the basic problems with historical earthquakes is the quality of intensities. There are very few catalogues of historical earthquakes which present both, unadulterated original macroseismic data and also the method used to assess intensities. Another problem is that there has been more emphasis on the development of methodology to analyse intensity data, than on the intensity data themselves.

At this stage of our studies it is not possible to assign intensities to individual locations or magnitudes to different events. The reason for this is that in determining the intensity of an historical earthquake at a place, and in assigning to that place an intensity rating in any scale, allowance has to be made for the vulnerability and rate of aging of buildings at that time, as compared with the vulnerability of man-made structures in those countries for which modern scales were originally drawn up. The building stock in the 12th century in our region and its vulnerability are different from those for which modern intensity scales have been prepared, so that existing intensity scales are not appropriate. Our uncertain knowledge of region-specific intensity attenuation scaling laws for that period has yet to be improved (see above Assessment of Intensity; Ambraseys and Bilham, 2003).

\section{Case histories}

All the earthquakes discussed below, as a matter of principle, are documented as fully as possible. Inevitably, however, there are cases where such thoroughness is misplaced when near-contemporary or later historical references, as well as early editions of Muslim writers that could have been easily omitted, are included for the sake of completeness, and also because this material had to be read through in the expectation of finding additional information, even when eventually they do not always add very useful or relevant details. 
As the aim of this article is to present as clearly as possible all the information on which the assessment is based, modern earthquake catalogues and studies are not cited unless they contain fresh and reliable information such as those of Alexandre (1990).

10 August 1114 - The large earthquake of 29 November 1114 - see below - was preceded by two strong shocks: the first of which, on the Feast of St Laurence, 10 August 1114 (Fulcher, RHC Hist. Occid., 1866), was probably felt in Antioch, and allegedly «caused damage to maritime cities and fortified towns with loss of life» which, as these cities are not named, may be pure rhetoric (William of Tyre, RHC Hist. Occid., 1844; Walter the Chancellor, RHC Hist. Occid., 1895; Robert de Torigni, Delisle, 18721873). But it is possible that what we have here is an earthquake with an epicentre offshore in the Bay of Iskenderun (Alexandretta). Aftershocks continued for two months (Gesta, Bongars, 1611; see also RHC Hist. Occid., 1866, though it dates it in 1113).

13 November 1114 - The second shock, for which we have information, occurred on $\mathrm{St}$ Bricious' day (William of Tyre, RHC Hist. Occid., 1844) or on the day of the Ides of November, 13 November 1114 (Sigebertus Gemblacensis, MGH SS, 6, 1844; see also Alexandre, 1990), and affected the south-eastern part of the plain of Adana, in the Principality of Antioch. The earthquake destroyed a part of Maras (Mamistra, Germanicea) (Gesta, Bongars, 1611; see also RHC Hist. Occid., 1866) and allegedly all the towns in the surroundings of the city (Walter the Chancellor, RHC Hist. Occid., 1895), causing great loss of life (Fulcher, RHC Hist. Occid., 1866). The neighbourhood of Antioch and the city itself suffered less, but in the suburbs of Antioch the ground opened up and a number of towers and houses nearby settled into the ground (Sigebertus Gemblacensis, MGH SS, 6, 1844), probably as a result of liquefaction of the ground. Many other towns in CaeloSyria, Isauria and Cilicia, the name of which is not given, were also affected (William of Tyre, RHC Hist. Occid., 1844). The large earthquake that followed a few weeks later obscures more details about this earthquake (Flores Historiarum, Luard, 1890; Robert de Torigni, Delisle, 1872-1873; William of Tyre, RHC Hist. Occid., 1844; Romoald of Salerno, RIS 2, 1909-1935 and MGH SS, 19, 1866).

29 November 1114 - The earthquake of 29 November 1114 occurred at night and affected the Christian County of Edessa and Principality of Antioch, which lie around the present borders of southern Turkey and northern Syria (fig. 2 ). The shock occurred at a time of almost continuous conflict between Christian and Muslims states. It was strongly felt to the east and southeast in neighbouring Muslim territory as well as to the north in Armenian and Turkish states.

The earthquake occurred at night on the Sunday of the vigil of St Andrew's day, 29 November 1114 (Walter the Chancellor, RHC Hist. Occid., 1895). Although there are not many contradictions between the sources, they vary about the date of the event. Out of about 25 authors who mention the event, three give the year as 1113,16 agree on 1114 , and 5 put it in 1115 (Anselmus Gemblacensis, PL, 160, 1854), all of them providing texts the details of which are those of the earthquake of 29 November 1114 (see also Alexandre, 1990). A few of the wrong dates are clearly copyist error adopted by later writers, as well as due to the amalgamation of the main shock with its fore- and aftershocks, a typical habit of later sources, particularly with Syriac writers who drew heavily on earlier material. This would also account for the few references to an earthquake in 1115 . In fact, there is strong agreement about the date of the main shock between contemporary and near contemporary occidental sources that give the night of 29 November.

The earthquake affected most of all the part occupied by the Franks (William of Tyre, RHC Hist. Occid., 1844). It was felt in other parts such as in Mesopotamia, Syria and other regions (Ibn al-Athir, RHC Hist. Or., 1872). In those of the Muslims nothing unfortunate occurred (Matthew of Edessa, RHC DA, 1869).

Maras, a fortified town in the Principality of Antioch together with its suburbs (William of 


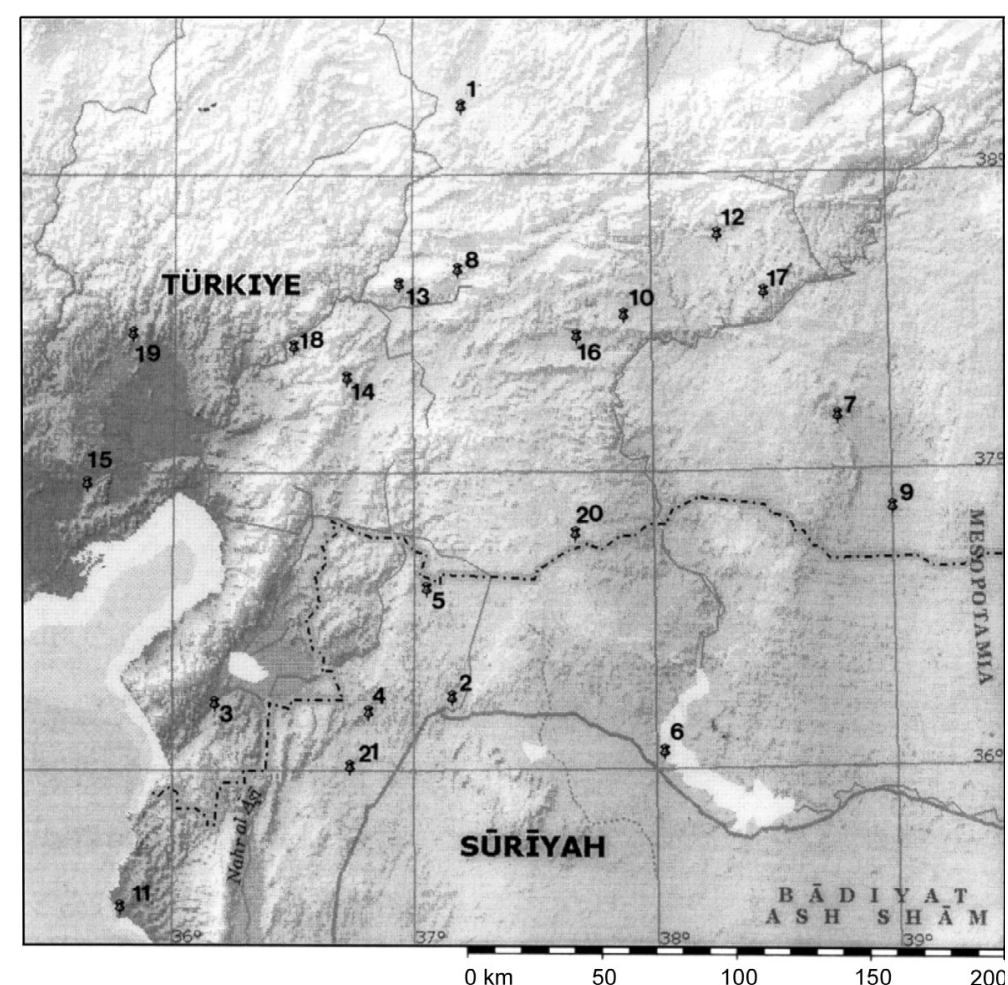

Fig. 2. Location map of the earthquake of 1114. 1 - Ablastha; 2 - Aleppo; 3 - Antioch; 4 - Atharib; 5 - Azaz; 6 Balis; 7 - Edessa; 8 - Hiesuvank; 9 - Harran; 10 - Kaysun; 11 - Latakiya; 12 - Mansur; 13 - Maras; 14 - Maschegavor; 15 - Mopsuestia; 16 - Raban; 17 - Samosata; 18 - Shoughr; 19 - Sis; 20 - Tell Khalid; 21 - Zaradna.

Tyre, RHC Hist. Occid., 1844), was almost totally destroyed with great loss of life (Fulcher, RHC Hist. Occid., 1866). Houses and the city walls, which were not in good condition, the fort (Robert de Torigni, Delisle, 1872-1873) and its ramparts (Abul Faraj, Bedjan, 1932) all were completely demolished (Flores Historiarum, Luard, 1890). The Church of Mar John of Kaysun collapsed, along with the Church of the Forty Martyrs (Michael the Syrian, Chabot, 1899-1910) and among those killed in the town were the Constable, the Bishop, the clergy and many important people (Walter the Chancellor, RHC Hist. Occid., 1895). Large parts of the villages belonging to Maras, which are not named, also collapsed (Michael the Syrian, Chabot, 1899-1910).
It is said that Maras was a very populous city and that between 24000 (Abul Faraj, Bedjan, 1932) and 40000 (Matthew of Edessa, RHC DA, 1869; Sembat, RHC DA, 1869) persons lost their lives, besides strangers, and more than 100 priests and deacons (Chronicon 1234, CSCO SS, 56, 1937; Gesta, Bongars, 1611; see also RHC Hist. Occid., 1866). The casualty figures are naturally suspect as they are comparable if not larger with the population of Maras; they sound like a biblical formula for a multitude.

The monastery of Mashchgavor (Mashkur), which must be sought near the north part of the Amanus Mt. (Giaour Dagh) (Dulaurier, 1861), also fell, killing among others the Armenian doctor Gregory (Matthew of Edessa, RHC DA, 1869). 
The same happened to Shoughr, the monastery of the Brasilians on the Black Mountains (Lersar), which is between Maras and Sis (Missis, Kozan) about $50 \mathrm{~km}$ from the former (Dulaurier, 1861), was also ruined and its church collapsed killing thirty monks and two officiating priests (Matthew of Edessa, RHC DA, 1869; Sembat, RHC DA, 1869).

A similar incident is reported from the monastery of Hiesuvank near Maras: it fell crushing all the religious under its ruins (Matthew of Edessa, RHC DA, 1869; Dulaurier, 1861).

Raban was almost totally destroyed (Matthew of Edessa, RHC DA, 1869; Sembat, RHC DA, 1869) and the same happened to Kaysun (Matthew of Edessa, RHC DA, 1869; Abul Faraj, Bedjan, 1932). It seems that damage at Mansur (Hisn Mansur) was serious but not excessive (Matthew of Edessa, RHC DA, 1869; Chronicon 1234, CSCO SS, 56, 1937; Sembat, RHC DA, 1869).

Samosata (Sumaisat) built on the left bank of the Euphrates River, was badly damaged (Matthew of Edessa, RHC DA, 1869). Houses in some parts of the town collapsed and elsewhere sunk into their foundations (Fulcher, RHC Hist. Occid., 1866; Ibn al-Jauzi: ed. Hyderabad 1938-1941 and Cairo Nat. Lib., M. 95; Ibn al-Athir, RHC Hist. Or., 1872; Sembat, RHC DA, 1869). According to a chronicler, they disappeared under the ground (al-Suyuti, Abd al-Latif Sa'adani, 1971), killing a number of people among them Constantine the lord of Gargar (Michael the Syrian, Chabot, 18991910; Abul Faraj, Bedjan, 1932) but not his jailers or other Franks. It is possible that much of the destruction was due to ground failures enhanced by the Euphrates River overflowing and flooding the town, which happened shortly before or after the earthquake in Samosata as well as in other places (Sibt ibn al-Jauzi, ed. Chicago 1907).

Little we know about Elbistan (Ablastha, Zeitun) where damage should not have been very serious (Sembat, RHC DA, 1869). We are told that Tell Khalid (Trialeth), a fortified site at the head of Sadjour Suyu, a tributary of the Euphrates River, was also destroyed (Fulcher, RHC Hist. Occid., 1866; Flores Historiarum, Luard, 1890; William of Tyre, RHC Hist. Occid.,
1844; Robert de Torigni, Delisle, 1872-1873; Gesta, Bongars, 1611; see also RHC Hist. Occid., 1866).

The earthquake was strongly felt in the district of Aleppo. In the city itself there was no damage to speak of, but near-by Azaz, a fort already in ruins, was badly damaged, and its governor fled to Aleppo (Kemal al-Din, RHC Hist. Or., 1884).

Damage in Aleppo was minimal, but about $25 \mathrm{~km}$ southwest of the city, the fortified site of Athareb was almost completely ruined (Kemal al-Din, RHC Hist. Or., 1884), which is not surprising as two years earlier, the siege engines of the Franks had pounded its walls to pieces, leaving little standing to be shaken down by the earthquake (see references in Runciman, 1952). Zerdana, $10 \mathrm{~km}$ south of al Athareb had the same fate (Kemal al-Din, RHC Hist. Or., 1884).

In the Principality of Antioch the earthquake caused great concern but otherwise only sporadic damage (William of Tyre, RHC Hist. Occid., 1844; Benedict of Accolti, RHC Hist. Occ., 1895). In the city itself people fled their homes in panic but since the walls remained intact, no one could escape and many fled to the church of the Apostle Peter, seeking his protection. From what we know damage was confined to the collapse of the tower of the north gate, of a few houses in a part of the city centre, as well as in the new, upper district (al akaba) of the city where a few people lost their lives (Kemal al-Din, RHC Hist. Or., 1884; Gesta, Bongars, 1611; see also RHC Hist. Occid., 1866).

In the suburbs of Antioch, the earth opened up, presumably as a result of incipient sliding or liquefaction of the ground, causing some damage. The patriarch proclaimed three days of fasting, but the authorities did not hurry what was to be done about repairs and the condition of the whole city (Walter the Chancellor, RHC Hist. Occid., 1895). They organised repairs asking inhabitants to contribute according to their means (Rey, 1896) and toured chief fortresses in the district for repairs (Rey, 1901). Contrary to what many near-contemporary sources imply, there is no mention in the contemporary sources of extensive damage, let alone that the city collapsed (Sembat, RHC DA, 1869) - for one thing, churches were left 
standing to which people took refuge (Cahen, 1940).

Repairs carried out after the earthquake suggests that the earthquake was rather strong in Latakia.

The site of Balis (Balash) was a former town in Syria and a port on the Western bank of the Euphrates $5 \mathrm{~km}$ from modern Meskene. Almost all writers say that the earthquake ruined 100 houses burying many people in the debris and caused the collapse of half of the citadel while the rest of the town stayed secure (Ibn alJauzi, ed. Hyderabad 1938-1941 and Cairo Nat. Lib., M. 95; Ibn al-Athir, RHC Hist. Or., 1872; Abul Faraj, Bedjan, 1932; al-Suyuti, Abd alLatif Sa'adani, 1971; Ajami Abu Darr, Sauvaget, 1950). But we are also told that soon before or after the earthquake, which should have been felt at Balis, the Euphrates River overflowed, ruining 100 houses and sweeping away half of the citadel (Sibt ibn al-Jauzi, ed. Chicago 1907). It is hard to decide between the earthquake and the flood for the loss of 100 houses and citadel.

In Edessa (Ruha, Urfa) the earthquake occurred almost immediately after the Muslims, who were besieging the city for two months, withdrew. The shock was felt in the Edessan countryside where the mountains and hills were shaken violently (Matthew of Edessa, RHC DA, 1869). Muslim sources say that 13 towers of the city wall collapsed (Ibn al-Jauzi, ed. Hyderabad 1938-1941 and Cairo Nat. Lib., M. 95; Abul Faraj, Bedjan, 1932; al-Suyuti, Abd al-Latif Sa'adani, 1971; Ajami Abu Darr, Sauvaget, 1950) with some loss of life (Ibn al-Athir, RHC Hist. Or., 1872). Oddly, Frankish sources, which mention a flood shortly after the earthquake that demolished the near-by dam, do not mention any damage in Odessa (sic) caused by the earthquake.

The old walls of Harran were breached here and there and houses were ruined killing a number of people (Ibn al-Jauzi, ed. Hyderabad 1938-1941 and Cairo Nat. Lib., M. 95; Ibn alAthir, RHC Hist. Or., 1872; Kemal al-Din, RHC Hist. Or., 1884; Abul Faraj, Bedjan, 1932; al-Suyuti, Abd al-Latif Sa'adani, 1971; Ajami Abu Darr, Sauvaget, 1950).

Little we know of what happened in Sis except that the town was again damaged and that many villages and monasteries in the plains of its district were destroyed with casualties (Matthew of Edessa, RHC DA, 1869; Sembat, RHC DA, 1869; Cahen, 1940).

The earthquake was not felt in Damascus where news of the earthquake arrived some days after the event (Ibn al-Jauzi, ed. Hyderabad 1938-1941 and Cairo Nat. Lib., M. 95). It is probable that the shock was perceptible $(G e$ sta, Bongars, 1611; see also RHC Hist. Occid., 1866) in Jerusalem but that damage extended that far (Romoald of Salerno, RIS 2, 19091935) might be dismissed as gross exaggeration. There is some evidence, however, that this or another earthquake shock about the same caused some concern (Enlart, 1925).

We could not substantiate the statement that as a result of the earthquake the sea got up (Sembat, RHC DA, 1869) causing some damage, spurious information, perhaps belonging to the earthquake of 10 August 1114.

Apparently only the Frankish-occupied provinces were badly damaged. Recorded repairs of damage in Muslim territory was chiefly to the mosques which was caused by the earthquakes or by other causes allotting to the repairs the silver which remained from the treasure of the waqf.

1 January 1120 - A violent earthquake destroyed many places (Michael the Syrian, Chabot, 1899-1910) at the 3rd hour of Thursday, 1st of Kanun-II, 1431; the date given corresponds to 1 January 1120 , which was a Thursday. No location is given, but as Michael's source for many events in this period is Basil of Edessa (Michael the Syrian, Chabot, 18991910), it is quite probable that the earthquake happened in the locale of that city.

February 1127 - An earthquake was felt, probably in Edessa. This event is recorded by Michael the Syrian (Michael the Syrian, Chabot, 1899-1910) and dated to a.S. 1438 in the month of Šebat (February 1127). He gives no location.

November 1127 - Two earthquakes during the day were followed by two more at night, with a long period of aftershocks for «forty 
days and forty nights», which can be taken to mean «a long time». The location is not given.

This event is recorded by Michael the Syrian (Chabot, 1899-1910) and dated to a.S. 1439 in the month of Tesrin (November 1127). A much later source (15th century) implies that this may be the earthquake that sometime in 1128 caused considerable damage in Sur (Matteo Palmieri, RIS 2, 1906-1915).

11 October 1138 - A long series of damaging shocks occurred in Northern Syria continuing for three months between October and December 1138. The main shock occurred on 11 October 1138 and it was followed by many aftershocks (Ibn al-Qalanisi, Amédroz, 1908). alQalanisi, a contemporary chronicler in Damascus, places the first shock in a.H. 533, Tuesday 4 Safar (Tuesday 10 October 1138), the next during the night of (after the next) Friday, at twilight, which, as the Islamic system counts from the night before should be Friday 14 Safar (Thursday 20 October 1138). The next shock is not until 19 Safar (Wednesday 25 October), followed by another shock during the night of the following Wednesday (26 Safar = Tuesday 31 October-Wednesday 1 November), with the last one in the early hours of Friday (i.e. 28 Safar $=$ = Friday 3 November). A later author, Kemal al-Din, mentions only one shock in a.H. 533, Thursday 13 Safar (Thursday 19-20 October 1138), which does not add up to al-Qalanisi's date. The varied dates given in the sources suggest that it was difficult for witnesses to distinguish the main earthquake from other shocks, particularly if the event was a multiple earthquake. In any case, the sources' sense of dating and of chronological order are not always their strong points (see also Ibn al-'Adim, Dahhan, 1951). Later writers conflate this earthquake with the earthquakes of November 1137 in Jazira and the large event of 30 September 1139 in Ganjak. For instance the 15 th century Ibn Taghribirdi reports a loss of 230000 lives in the earthquake, which was worst in Aleppo (Ibn Taghribirdi, Shaltut, 1929-1972). In fact these losses were due to the earthquake in Ganjak in Georgia.

Following al-Qalanisi, the main shock should have been on 10-11 October 1138, a date supported by other sources (Kemal al-Din, RHC Hist. Or., 1884; al-'Umari, Ms., Iraq Acad., Baghdad; Ibn al-Athir, RHC Hist. Or., 1872 and Cairo 1885), and which we adopt for this event. The earthquake occurred in what was at the time the frontier territory between Moslems and Christian, in which most sites had already suffered from warfare and previous earthquakes.

Worst hit was the castle of Harim, which was occupied by the Franks (fig. 3). The castle was shattered and the Church collapsed (Michael the Syrian, Chabot, 1899-1910; Ibn Taghribirdi, Shaltut, 1929-1972).

Athareb, occupied by the Muslims, and already weakened by warfare and the earthquake 24 years earlier, was ruined and its citadel collapsed completely, killing 600 of the guard. The governor with a few survivors fled to Mosul. In this respect the earthquake benefited Athareb as he had taken possession of the region and raised taxes. The impromptu tax relief benefited reconstruction (Kemal al-Din, RHC Hist. Or., 1884; Michael the Syrian, Chabot, 1899-1910; Chronicon 1234, CSCO SS, 56, 1937; Ibn Taghribirdi, Shaltut, 1929-1972).

All we know about near-by Zaradna is that it was destroyed, which is not surprising as it had already been ruined a few years earlier $(\mathrm{Ke}$ mal al-Din, RHC Hist. Or., 1884; Deschamps, 1935). Little is known about the small fort at Shih, which was totally destroyed (Kemal alDin, RHC Hist. Or., 1884).

In Aleppo, a large city with a population of a few tens of thousand, the earthquake did considerable damage. The ramparts of the city buckled and the walls of the citadel were shattered (Ibn alQalanisi, Amédroz, 1908). Stones detached themselves from the walls fell into the streets, houses were destroyed, some house walls collapsed, and the two parts of the walls, east and west of the citadel were breached (Kemal al-Din, RHC Hist. Or., 1884).Warned by foreshocks people evacuated their houses and fled to the country (Ajami Abu Darr, Sauvaget, 1950; Abu 'l-Fida, RHC Hist. Or., 1872). Throughout the period 4th to 19 th Safar 533 a.H. (10 to 25 October) (Ibn alShihnah, British Library, London, Ms. Or. Add. 2, 36), the populace of Aleppo lived outside the city (Ajami Abu Darr, Sauvaget, 1950). 


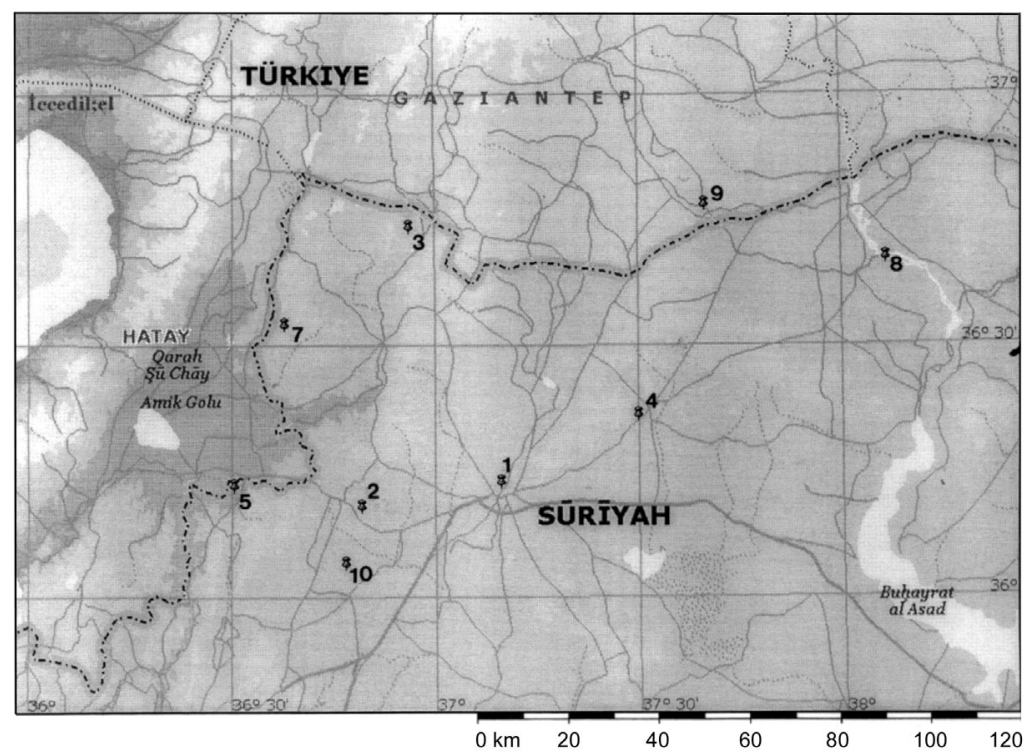

Fig. 3. Location map of the earthquake of 1138. 1 - Aleppo; 2 - Atharib; 3 - Azrab; 4 - Bizza; 5 - Harim; 6 Raqqa (120 kn SE of Tell Amar); 7 - Shih; 8 - Tell Amar; 9 - Tell Khalid; 10 - Zaradna.

Many sources, without giving any details regarding loss of life, repairs or tax relief, say briefly that Aleppo was destroyed (Michael the Syrian, Chabot, 1899-1910; al-Suyuti, Abd alLatif Sa'adani, 1971). However, not all sources agree that the shock reached its maximum at Aleppo and in the surrounding towns. Kemal's record shows that the damage to Aleppo was not great, the worst being the collapse of the nearby Atharib citadel (Kemal al-Din, RHC Hist. Or., 1884).

In Azrab, north of Aleppo on the edge of the Kuros Mountains, the ground opened in the middle of the village and later collapsed totally (Michael the Syrian, Chabot, 1899-1910; Ibn Taghribirdi, Shaltut, 1929-1972) most probably, as a result of a landslide triggered by the earthquake. At Bizaah the earthquake brought down towers from the walls (Michael the Syrian, Chabot, 1899-1910). All we know about Tell Khalid and Tell Amar, is that they suffered some unspecified damage (Kemal al-Din, RHC Hist. Or., 1884). The earthquake and some of its aftershocks were perceptible in Damascus but not in Jerusalem (Chronicon 1234, CSCO SS, $56,1937)$

Callinice (Nicephorium, Raqqa) on the Euphrates River is often associated wrongly with this earthquake on the authority of Michael the Syrian (Michael the Syrian, Chabot, 1899-1910).

After recording the damaging earthquake in Aleppo in a.S. 1450 Tesrin (October 1138), Michael moves on to his next item in which he mentions a severe winter from December to February, during which the Euphrates River freezes. Only after this does he mention the opening of the ground and the swallowing up of 40 men near Callinice (Raqqa). This incident, which is repeated by later writers in 1140 (Abul Faraj, Bedjan, 1932), he does not connect with the 1138 earthquake, nor does he imply that the opening of the ground was the result of an earthquake. There is no evidence that the shock was responsible for the reported effects at Raqqa, or that it extended beyond (al-Tabbakh, ed. Aleppo 1923).

27 September 1151 - An earthquake occurred during the night in the area of Bostra and 
the Hauran in SE Syria and was felt widely in neighbouring districts. There were three shocks altogether, at least one of which must have been damaging, as a large number of walls were reported to have collapsed in Bostra and in other places (Ibn al-Qalanisi, Amédroz, 1908)

It is not certain that the shock was felt in Damascus. Ibn al-Qalanisi says that «accounts came to us» (probably orally, in the first instance) about an earthquake during the night of (i.e. preceding) a.H. 546 13th latter Jumada (27 September 1151).

27 September 1156 - A strong earthquake caused considerable concern in Damascus, «In the 8th hour of the night of Thursday 9 Shaban 551» (27 September 1156) (Ibn al-Qalanisi, Amédroz, 1908). Shock continued until the end of the day. The long series of earthquakes which were felt in Damascus after this data, is recorded by this author, from whose work many later chroniclers have drawn, in the process committing a variety of dating errors.

10 October 1156 - There were more shocks felt in Damascus but less intense (Ibn alQalanisi, Amédroz, 1908). According to the same author and to al-Suyuti (Abd al-Latif Sa'adani, 1971) in the night of Wednesday 22 Shaban 551 (10 October 1156) an earthquake happened on Saturday night 25 Shaban 551 (13 October 1156). Gregory the Priest, the continuator of Matthew of Edessa (RHC DA, 1869) gives exactly the same description of the event but dates it to 26 October. Shocks were felt in Damascus on Wednesday 29 Shabban $551=17$ October 1156, Monday 1 Ramadan $=18$ October, Tuesday Ramadan $3=20$ October, Friday night 15 Ramadan $=1$ November, Saturday 16 Ramadan $=2$ November, at night 17 Ramadan $=3$ November, Friday night 23 Ramadan $=9$ November, on Sunday 2 Shawwal $=18$ November, Thursday 7 Shawwal $=22$ November, Monday 16 Shawwal $=2$ December, 17 Shawwal $=3$ December, 22 Shawwal $=6$ December.

2 April 1157 - Another earthquake was strongly felt in Damascus after sunrise and the following morning, causing great consternation among the inhabitants, on Wednesday 19 Safar 552 (2 April 1157) (Ibn al-Qalanisi, Amédroz, 1908). The shock had considerable effects in northern Syria (al-Suyuti, Abd al-Latif Sa'adani, 1971; Abu Shama, Hilmi, 1956-1962), the exact nature of which is unknown, but probably it was damaging. It was followed by another shock on the same day (Ibn al-Qalanisi, Gibb, 1932) and more shocks the following days (Thursday night 20 Safar $552=3$ April 1157; 21 Safar $=4$ April, 21 Jumada $=1$ July, Thursday 25 Jumada $=5$ July).

13 July 1157 - This was damaging, probably at midday Sunday 4 Jumada-II = 13 July, which was followed by a single aftershock, possibly during the night (Ibn al-Qalanisi, Amédroz, 1908; al-Suyuti, Abd al-Latif Sa'adani, 1971).

Homs (Hims Emessa), Hama (Hamath, Epiphanea), Shaizar, and Kafrtab were partly ruined. Repairs were affected after the last earthquake had damaged (al-Suyuti, Abd alLatif Sa'adani, 1971) or destroyed them (Ibn al-Qalanisi, Amédroz, 1908). It seems that damage in Apamea (Afamya, Qalat al Mudiq) was less serious (Abu Shama, RHC Hist. Or., 1896). The earthquake did some slight damage in Aleppo and it was felt in Damascus, and strongly at Tayma, south of Damascus (Ibn alQalanisi, Amédroz, 1908; al-Suyuti, Abd alLatif Sa' adani, 1971).

As a result of the cumulative damage caused by the long series of earthquakes to the defences of the region of Aleppo, particularly to the frontier forts of Homs, Shaizar, Kaftab and Hama, the Frankish armies were preparing to invade the country in the hope of profiting from the earthquakes which had just ruined the forts, citadels and houses of the Muslims (Abu Shama, RHC Hist. Or., 1896). Nureddin set out to repair the defences of Hims, Shaizar, Kafr-tab and Hamah on a.H. 552 Rajab 3 (11 August 1157), and he makes it clear that this was because he had heard that the Franks were preparing to invade the country in the hope of profiting from the earthquakes. This confirms that the cumulative damage caused by all these earthquakes was serious and predates the additional damage caused by the large earthquake of 12 August 1157. 
12 August 1157 - The culmination of over a year of foreshocks was a violent earthquake in the northern section of the Dead Sea fault zone (fig. 4).

The most part of Syria, in the districts where there was no destruction, was damaged (Ibn alAthir, RHC Hist. Or., 1872 and Cairo 1885; Abu Shama, RHC Hist. Or., 1896), and had it not been for prompt response by the Muslims to defend the country, the Franks would have taken possession of it without siege or combat (Abu Shama, RHC Hist. Or., 1896). The situation was the same in the Frankish possessions (Kemal al-Din, RHC Hist. Or., 1884 and ROL, 1896; see also Röhricht, 1874). The earthquake was so violent that ramparts and castles were overturned by it both sides busying themselves in repairing the damaged fortifications and in making sallies into each others possessions in order to confine the enemy back in their own territory (Abu 'l-Fida, RHC Hist. Or., 1872; Ibn Wasil, Shayyal, 1962).

The earthquake occurred during the night (on the 7th hour) of Monday, 4 Rajab a.H. 552 (12 August 1157) (Ibn al-Qalanisi, Amédroz, 1908 and Gibb, 1932; al-Suyuti, Bibliotèque Nationale de France, MSS Ar. 5929; Ibn alAthir, RHC Hist. Or., 1872 and Cairo 1885). There is some confusion possible with the earthquake that followed in 1170, particularly in some later writers, which is not difficult to disentangle (Ibn Kathir, Cairo 1932-1939; Ibn al-Furat, Basra 1967; al-Aini, Bibliotèque Nationale de France, Ms. Arabes 5761; alQalqashandi, Ferraj, 1964; Ajami Abu Darr, Sauvaget, 1950; al-'Umari, Ms., Iraq Acad., Baghdad; Matthew of Edessa, RHC DA, 1869; Nicetas Choniates, Bekker, 1835; Gregory the Priest, RHC DA, 1869).

The epicentral region of the earthquake may be defined by the localities Maraat an-Numan. Kafertab, Apamea, Shaizar, Hama, Masyaf, and Barin, a zone about $120 \mathrm{~km}$ long running in a north-south direction along the el Rhab and the Orontes Valley.

In Maarrat an-Numan damage was very serious. Public buildings collapsed and the minaret of the Grand Mosque was damaged and repaired (Elisseeff, 1951). Despite later sources, which say that no one survived, loss of life was not ex- cessive (Ibn al-Jauzi, ed. Hyderabad 19381941). The town received $8.2 \mathrm{~kg}$ of gold in tax relief (Abu Shama, RHC Hist. Or., 1896). Kafertab suffered almost total destruction (Elisseeff, 1967) and very few of its inhabitants es-

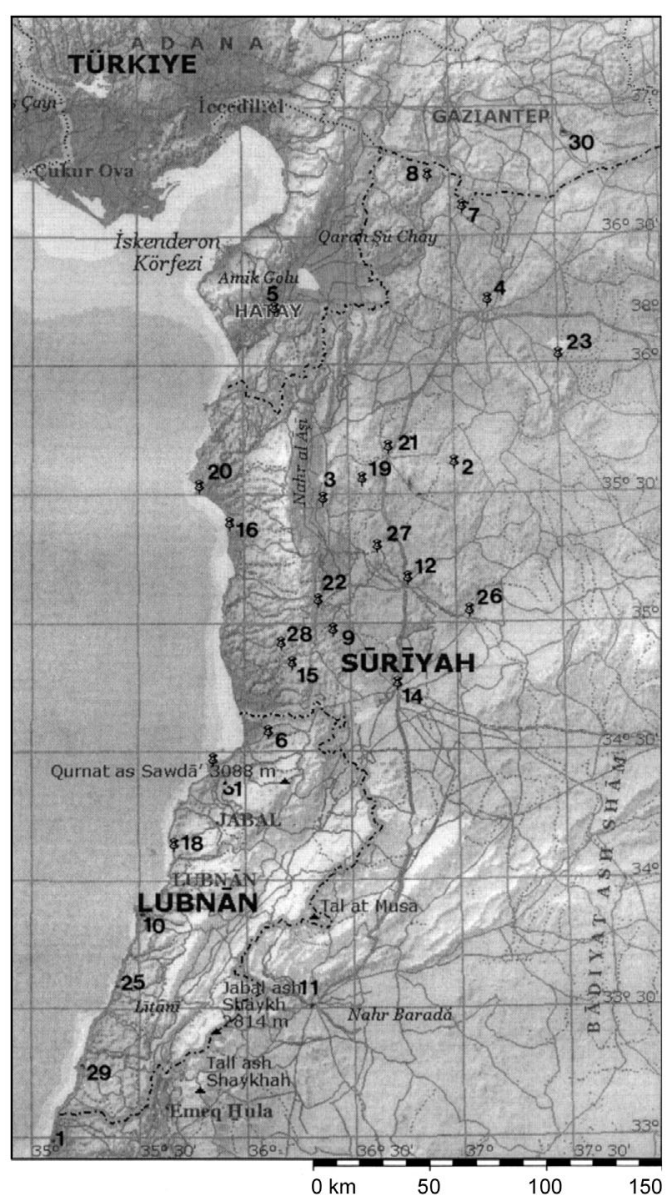

Fig. 4. Location map of the earthquake of 1157.1 Acre; 2 - Adad al-Arab; 3 - Afamiya; 4 - Aleppo; 5 Antioch; 6 - Arqa; 7 - Azaz; 8 - Azra; 9 - Barin; 10 Beirut; 11 - Damascus; 12 - Hama; 13 - Harran; 14 Hims; 15 - Hisn al-Akrad; 16 - Jebeleh; 17 Jerusalem; 18 - Jubail; 19 - Kafertab; 20 - Latakiya; 21 - Maarat al-Numan; 22 - Masiyaf; 23 - Nisfin; 24 - Rahba; 25 - Saida; 26 - Selemiyeh; 27 - Shaizar; 28 - Shoumaimis; 29 - Sur; 30 - Tell Bashir; 31 Tripolis. Jerusalem and Rahba are out of the map. 
caped (Michael the Syrian, Chabot, 1899-1910; Ibn al-Jauzi, ed. Hyderabad 1938-1941; Ibn alAthir, RHC Hist. Or., 1872 and Cairo 1885; Chronicon 1234, CSCO SS, 56, 1937).

In Apamea, which is built on the edge of a plateau on the right bank of the Orontes River at its northward bend, the earthquake caused equally heavy damage and loss of life (Michael the Syrian, Chabot, 1899-1910; Ibn al-Athir, RHC Hist. Or., 1872 and Cairo 1885; Chronicon 1234, CSCO SS, 56, 1937). Its citadel was destroyed (Ibn al-Jauzi, ed. Hyderabad 19381941), most probably by a landslide, which tipped the fortress into a lake, which resulted in many deaths (Ibn Taghribirdi, Shaltut, 19291972). There is no evidence that the castle was rebuilt (Berchem and Fatio, 1913) but the walls of its citadel were repaired (Elisseeff, 1951 and 1967). The ruins of the town still exist, flanked on the west by the later citadel of Qalat alMadik (nr. Apamea).

At Shaizar (Ibn al-Jauzi, Nat. Lib., Cairo, Ms. 95, gives Shiraz for Sheizar) on the Orontes River, damage was heavy (Robert de Torigni, Delisle, 1872-1873; Yaqut al-Hamawi, Wüstenfeld, 1866-1873; Abu Shama, RHC Hist. Or., 1896; Chronicon 1234, CSCO SS, 56, 1937; Abu 'l-Fida, RHC Hist. Or., 1872; Ibn Taghribirdi, Shaltut, 1929-1972). Its castle, which was the seat of the local ruling family, fell down upon its governor and his followers, killing all but two. Its citadel totally collapsed as well as all the buildings, which it enclosed, and only a small number of people managed to flee and escape (Michael the Syrian, Chabot, 1899-1910; Ibn al-Jauzi, ed. Hyderabad 1938-1941; Ibn alAthir, RHC Hist. Or., 1872 and Cairo 1885; alSuyuti, Bibliotèque Nationale de France, MSS Ar. 5929). We hear that «half of the mountain on which the citadel was built collapsed» suggesting that damage was enhanced by a landslide. The suburb of Shalimar escaped, except for what had been destroyed earlier (Ibn alQalanisi, Gibb, 1932; Ibn al-'Adim, Dahhan, 1951). Again here it is difficult to estimate loss of life which is given descriptively as «a countless multitude» (Ibn al-Athir, RHC Hist. Or., 1872 and Cairo 1885), or 40000 people (Shaizar «was demolished», 40000 dying there: this must be a gross exaggeration, Chronicon
1234, CSCO SS, 56, 1937). As the earthquake had ruined the castle and its ramparts had been overturned the Muslims took possession of the town, rebuilding the houses (Ibn al-Athir, RHC Hist. Or., 1872 and Cairo 1885) and the citadel (Elisseeff, 1951). The fort was repaired but not necessarily rebuilt (Berchem and Fatio, 1913). The town was probably not totally destroyed (Ibn al-Qalanisi, Gibb, 1932), but as it was of strategic importance and its main defense had been destroyed, it was granted a year's tax relief of only $2.7 \mathrm{~kg}$ of gold (Abu Shama, RHC Hist. Or., 1896). The reason for the tax relief at the same time as the Muslims took possession of Shaizar, is that the towns in question could not afford «to repair the damage done by the Franks». Our source makes not mention of earthquakes as the reason for the tax relief, but it cannot be insignificant that among these towns are all but those damaged by the earthquake. One should be cautious about inferring the size of the damage from the size of the relief (see also the cases of Maarrat an-Numan, above, and Homs, Adad al Arab, Aleppo, below).

Ibn al-Athir (RHC Hist. Or., 1872 and Cairo 1885 ) says that Shaizar was adjacent to Damascus, and that these two places were separated only by half a day's march, and that Shaizar was located on a high and impregnable mountain, and could be reached by only one road. For this mislocation see Dussaud (1927).

The city of Hama built on both banks of the Orontes River that at this point winds a great deal, was the worst affected. The town itself and all its large houses that were crowded close to the river (Chronicon 1234, CSCO SS, 56, 1937) collapsed and almost all the inhabitants perished. The citadel of the town built along the bank of the river, and its fortress were demolished (Chronicon 1234, CSCO SS, 56, 1937). There were few survivors (Michael the Syrian, Chabot, 1899-1910; Ibn al-Qalanisi, Gibb, 1932; Abu 'l-Fida, RHC Hist. Or., 1872; alSuyuti, Bibliotèque Nationale de France, MSS Ar. 5929). This is attested by the story that when the school collapsed on all of the children, the teacher who survived the earthquake said that none of the parents came to claim them (Ibn al-Jauzi, ed. Hyderabad 1938-1941; 
Ibn al-Athir, RHC Hist. Or., 1872 and Cairo 1885; Abu 'l-Fida, RHC Hist. Or., 1872; Ibn Taghribirdi, Shaltut, 1929-1972). A contemporary writer (Usama, Hitti, 1987) describes the deplorable situation in Hama in an elegy. It is not known how many people lost their lives. We know that repairs were made, because when Hama was damaged again by the earthquake of 30 October, according to one source «the structures which had been rebuilt were destroyed again. The wall of the citadels and the Hasanain mosque were rebuild (Elisseeff, 1951). An extant inscription on the wall of a small mosque, to the south of the citadel, indicates that this structure was repaired after it had been destroyed by the Hama earthquake (al-zalzala alhamawiyya) of a.H. 552 (Berchem and Fatio, 1913). However Hama is not recorded as having received any tax-relief.

It is probable that Masyaf was also ruined (Guyard, 1877) but details are lacking. The castle of Barin was seriously damaged ( $A b u$ Shama, RHC Hist. Or., 1896) and its walls were repaired after the earthquake (Elisseeff, 1951).

Less seriously affected localities were Shumaimis, Hisn al Akrad, Arqa, Tripolis, Homs, Adad al Arab, Salamiya, Aleppo and Jabealah.

At the citadel of Shumaimis the earthquake caused numerous deaths (Kemal al-Din, RHC Hist. Or., 1884 and ROL, 1896; see also Röhricht, 1874). Hisn al-Akrad in Frankish territory, contrary to what Muslim sources say that it was destroyed (Michael the Syrian, Chabot, 1899-1910; Ibn al-Athir, RHC Hist. Or., 1872 and Cairo 1885; Chronicon 1234, CSCO SS, 56, 1937; Abu 'l-Fida, RHC Hist. Or., 1872), it was badly damaged and some lives were lost (Kemal al-Din, RHC Hist. Or., 1884 and ROL, 1896; see also Röhricht, 1874). The damage was quickly repaired and the castle enlarged.

Arqa (Arches), in Frankish territory, was probably badly damaged. According to Muslim sources the town completely collapsed (Michael the Syrian, Chabot, 1899-1910) and countless multitude died (Ibn al-Athir, RHC Hist. Or., 1872 and Cairo 1885) for which there is no indication in occidental sources.

Damage in Tripoli should have been less serious than Muslim writers describe. They say that most parts of Tripolis were destroyed (Michael the Syrian, Chabot, 1899-1910; Chronicon 1234, CSCO SS, 56, 1937; Abu ' $l$ Fida, RHC Hist. Or., 1872; Ibn Taghribirdi, Shaltut, 1929-1972) and a countless multitude died (Ibn al-Athir, RHC Hist. Or., 1872 and Cairo 1885; Kemal al-Din, RHC Hist. Or., 1884 and ROL, 1896; see also Röhricht, 1874), which is very dubious. A contemporary Hebrew source (Benjamin of Tudela, Adler, 1907) has two unconnected records of the damage caused by this earthquake: the first is of the collapse of Tripoli in an earthquake «in years gone by», with «great destruction in the Land of Israel» which killed some 20000 people. His second record is of an earthquake «some time ago»: apparently the 1170 event which in one day it killed some 25000 people, «and of about 200 Jews but 70 escaped».

Homs is on the eastern bank of the Orontes in the centre of a plain. It suffered less serious damage than some authors report (Ibn al-Jauzi, ed. Hyderabad 1938-1941; Ibn al-Athir, RHC Hist. Or., 1872 and Cairo 1885). The citadel (Michael the Syrian, Chabot, 1899-1910), monasteries (Chronicon 1234, CSCO SS, 56, 1937) and most of its buildings were ruined, but the death toll was low as the population fled to the outskirts (Ibn al-Qalanisi, Gibb, 1932; alSuyuti, Bibliotèque Nationale de France, MSS Ar. 5929) during the foreshocks (Michael the Syrian, Chabot, 1899-1910). It received tax relief of $71 \mathrm{~kg}$ of gold (Abu Shama, RHC Hist. Or., 1896).

Nothing is known about the effects of the earthquake on Adad al Arab the location of which is questionable (Dussaud, 1927), except that it received the considerable sum of $27.2 \mathrm{~kg}$ of gold as tax relief ( $A b u$ Shama, RHC Hist. Or., 1896). Salamiya was also damaged severely and a great number of people died in the town and in many neighboring villages (Ibn al-Qalanisi, Gibb, 1932; Kemal al-Din, RHC Hist. Or., 1884 and ROL, 1896; see also Röhricht, 1874), but is not recorded as having received tax relief.

Damage in Aleppo, a city of about 70000 inhabitants, was widespread and in certain places serious. Some of the towers of the fortifications collapsed together with some houses (Michael the Syrian, Chabot, 1899-1910; Ibn 
Taghribirdi, Shaltut, 1929-1972) and the wall between the Bab al-Jinan and Bab Qinnarsin was damaged and repaired after the earthquake (Elisseeff, 1951 and 1967). Most of the inhabitants left the city during the foreshock period (Ibn al-Qalanisi, Gibb, 1932; Chronicon 1234, CSCO SS, 56, 1937) and only about 100 to 500 were killed (Ibn al-Jauzi, ed. Hyderabad 19381941). It is odd that Kemal (Kemal al-Din, RHC Hist. Or., 1884 and ROL, 1896; see also Röhricht, 1874) adds nothing on the damage to Aleppo, as he would presumably have had access to local archives: however, his silence suggests that he accepts Ibn al-Jauzi's figure of 100 deaths, as opposed to the 500 given by other sources (Michael the Syrian, Chabot, 18991910). Following the earthquake taxes were abolished to the amount of $136 \mathrm{~kg}$ of gold ( $\mathrm{Abu}$ Shama, RHC Hist. Or., 1896).

Jubail (Byblus) sustained some unspecified damage (Ibn al-Qalanisi, Gibb, 1932). Outside this region damage was widespread but not serious. The walls of Nisfin, probably a village lying near Aleppo (Yaqut al-Hamawi, Wüstenfeld, 1866-1873) were damaged (Ibn Taghribirdi, Shaltut, 1929-1972); Tell Nasfin, too, is a hill near Aleppo (Yaqut al-Hamawi, Wüstenfeld, 1866-1873). Tell Bashir, important frontier fort, also suffered some damage, and was given relief of $7.2 \mathrm{~kg}$ of gold (Abu Shama, RHC Hist. Or., 1896). Azaz, in the north, important frontier fort-towns, also suffered some damage, and was given relief of $27.2 \mathrm{~kg}$. (Abu Shama, RHC Hist. Or., 1896). At Arza there were numerous deaths (Kemal al-Din, RHC Hist. Or., 1884 and ROL, 1896; see also Röhricht, 1874).

The city of Antioch was far less seriously affected than Muslim sources imply. There is no evidence that «most parts of Antioch were destroyed» (Michael the Syrian, Chabot, 18991910; Ibn al-Athir, RHC Hist. Or., 1872 and Cairo 1885; Chronicon 1234, CSCO SS, 56, $1937)$, or that «the majority of the population was annihilated» (Kemal al-Din, RHC Hist. Or., 1884 and ROL, 1896; see also Röhricht, 1874), which is very dubious. It is probable that these sources refer to the Principality of Antioch that included most of the localities destroyed in this earthquake ( $A b u$ ' $l$-Fida, RHC Hist. Or., 1872).
Damage in Latakia should have been serious but not excessive as Muslim sources suggest (Ibn al-Athir, RHC Hist. Or., 1872 and Cairo 1885). The Great Church remained standing (Michael the Syrian, Chabot, 1899-1910; Chronicon 1234, CSCO SS, 56, 1937), and there is no evidence that the walls of the town were damaged.

It is said that as result of the earthquake the ground in the city split open, mud and water filling the cracks, revealing ancient ruins (Michael the Syrian, Chabot, 1899-1910; Kemal al-Din, RHC Hist. Or., 1884 and ROL, 1896; see also Röhricht, 1874; Chronicon 1234, CSCO SS, 56, 1937; Ibn Taghribirdi, Shaltut, 1929-1972), evidence suggesting liquefaction of the ground.

The castle at Jabalah was damaged but how much, it is not given in the sources (Ibn alQalanisi, Gibb, 1932). The shock should have been felt at Beirut, Saida (Sidon), Sur (Tyrus) and Acre (Akko), but it is rather unlikely that the earthquake ruined these localities, most probably oriental sources (Michael the Syrian, Chabot, 1899-1910; Ibn Taghribirdi, Shaltut, 1929-1972) exaggerating the damage to these Frankish coastal strongholds.

In Damascus the earthquake caused panic. With the first foreshock the people fled their houses (Ibn al-Qalanisi, Amédroz, 1908; Ibn Taghribirdi, Shaltut, 1929-1972). The shocks affected many parts of the city, and caused some damage to the Mosque of Damascus that shed quantity of mosaics and marble (al-Suyuti, Bibliotèque Nationale de France, MSS Ar. 5929). We cannot authenticate the assertion made by a near-contemporary writer (al-Suyuti, Bibliotèque Nationale de France, MSS Ar. 5929) that the mosque itself collapsed (since Ibn al-Qalanisi, who was an eyewitness, does not refer to damage in Damascus and to the collapse of the mosque, it is not improbable that Abu Shama confused the 12 August event with another earthquake). The city was granted tax relief of $57 \mathrm{~km}$ of gold, not so much for repair but as an assistance to the inhabitants whose fortunes had been lost by the attacks of the Franks, and also for their inability to meet the annual tax (Abu Shama, RHC Hist. Or., 1896). 
Repairs to the Mosque in Baalbek suggest that this old structure had suffered some damage from this earthquake (Elisseeff, 1951 and 1967) or from a later shock (Berchem and Fatio, 1913), information not found in the sources.

Modern writers extend the destructive effects of the earthquake to Harran in Jazirah. It is possible that the shock was felt as far as Harran but the sources do not say explicitly that the city was destroyed or even damage by the shaking of the ground (Ibn al-Jauzi, ed. Hyderabad 1938-1941; Ibn Taghribirdi, Shaltut, 19291972). What they say is that, as a result of the earthquake the hill, or a part of it, on which the city is built opened up causing the collapse of many houses, and the cleft in the ground revealing tombs and old houses. This fits the description of a landslide in recent deposits overlying earlier urban debris, triggered by the shock. As for the financial aid of $13.6 \mathrm{~kg}$ of gold given to Harran (Abu Shama, RHC Hist. Or., 1896), this could have been used to enlarge the Friday Mosque, which became necessary since in recent years the number of Muslims had greatly increased. Ibn Jubayr, who passed through Harran in 1184, gave a detailed account of the city and New Mosque, an inscription on which gives the date of its enlargement as 1174 .

Also for Rahba (Mayadin) on the Euphrates, the sources do not imply that the town suffered any damage or even that the shock was felt there (Michael the Syrian, Chabot, 1899-1910; Ibn al-Qalanisi, Gibb, 1932; Chronicon 1234, CSCO SS, 56, 1937). They say that the earthquake effects spread towards Rahba and all the regions of Iraq. This is an indicator of the direction in which the shock was felt. The reason for the abolition of taxes of 10000 dinars (Abu Shama, RHC Hist. Or., 1896) was probably not for the repair of earthquake damage but for the repair war damage.

As for the statements that the earthquake affected Ararat (Ibn al-Jauzi, ed. Hyderabad 1938-1941) and that damage extended to Cyprus (Elisseeff, 1967), we can find no evidence. The only earthquake felt in Cyprus near this time occurred in 1160 (Neophytus, Delahaye, 1907).

Aftershocks continued to be felt over a long period of time and are recorded Friday night 8
Rajab (16 August), Saturday night Rajab 9 (17 August); Saturday, Sunday and Monday, 9, 10 and 11 Rajab (17, 18, 19 August), and Monday 29 Rajab (6 September) (Ibn al-Qalanisi, Amédroz, 1908 and Gibb, 1932).

There is no doubt that large earthquakes cause considerable destruction, which is often followed by tax relief and grants awarded by the state for reconstruction. However, this is not always the sole reason. The tax relief after the 1157 earthquake was not for the repair of earthquake damage but because people could not afford to repair the damage done by the Franks to a number of towns and forts, which was enhanced by the earthquake. One should be cautious about inferring the degree of damage, even for modern events, from the size of the relief.

30 October 1157 - A violent aftershock caused great panic and more damage in Syria, Wednesday 24 Ramadan 552. In and around Hama, there were continual violent shocks for several days, and the buildings that had been rebuilt were reportedly destroyed again (Ibn alQalanisi, Amédroz, 1908).

In Aleppo many of the houses and defences were damage and some may have been destroyed (Ibn al-Qalanisi, Amédroz, 1908). The earthquake was strongly felt in Damascus, and there may have been damage, though Abu Shama (RHC Hist. Or., 1896), does not mention damage in Aleppo and Damascus. As the shocks went on they became weaker.

October 1158-September 1159 - The date of an earthquake, which allegedly destroyed Jabalah on the Syrian coast and as a result 2000 people were «drowned», cannot be fixed. Chronicon 1234 (CSCO SS, 56, 1937) dates the event in a.S. 1470 (October 1158-September 1159). If the sequence of events in the Chronicon 1234 is correct, it is likely that the earthquake happened sometime between those dates. This event is recorded only in one source and it may refer to the earthquake of 12 August (Chronicon 1234, CSCO SS, 56, 1937).

Aftershocks continued to be felt in Syria for a long time: on Saturday night 10 Shawwal (15 November), Saturday night 10 Dulqada (14 De- 
cember), Sunday night 21 Dulqada (25 December), Friday night 23 Dulqada (27 December), Sunday night 25 Dulqada (29 December 1157), Friday 30 Dulqada (3 January 1158), 15 Rabi-I (16 April), 25 Rabi-I (26 April), 23 Rajab (20 August), 24 Rajab (21 August), and Friday night 2 Jumada-II (21 Jun 1159).

29 June 1170 - For this earthquake we have several accounts by eyewitnesses, and virtually unanimity regarding the date from both occidental and oriental sources. Preceded by foreshocks, the earthquake occurred early in the morning of 29 June 1170, and it was as destructive as that of 12 August 1157. Its epicentral region overlaps that of the earthquake of 1157 , making it difficult to define its extent, which includes Shaizar, Hama, Barin, Safita, Hisn el
Akrad, Homs, Qusayr (n. Qalat el-Zau), Hisn alAkkar, Arqa and Baalbek (figs. 5 and 6).

In Shaizar the earthquake ruined what the war and the earthquake 13 years earlier had spared. It caused considerable destruction to the walls (Abul Faraj, Bedjan, 1932 and Salhani, 1890) and citadel (Ibn al-Athir, Cairo 1885; Tornberg, 1853; RHC Hist. Or., 1872; Talimat, 1963) and great parts of the town were destroyed (Kemal al-Din, 1896 and Röhricht, 1874), killing many people (William of Tyre, RHC Hist. Occid., 1844 and Babcock and Krey, 1943; Ibn al-Athir, Cairo 1885; Tornberg, 1853; RHC Hist. Or., 1872; Talimat, 1963). The town did not recover until 1232 when it was finally rebuilt (Mallet, 1853).

Hama, almost totally ruined thirteen years before and partly rebuilt, replacing many of its

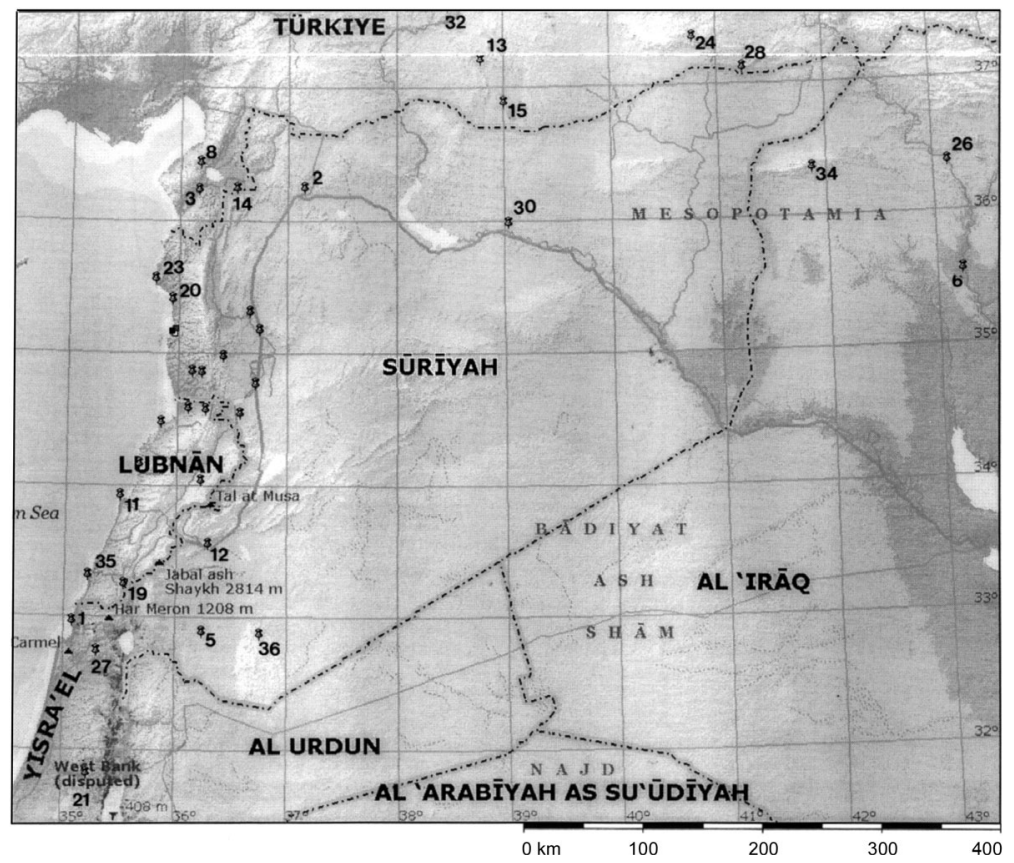

Fig. 5. Location map of the earthquake of 1170. 1 - Acre; 2 - Aleppo; 3 - Antioch; 4 - Arqa; 5 - Ashtera; 6 Ashur; 7 - Baalbek; 8 - Baghras; 9 - Bannyas; 10 - Barin; 11 - Beirut; 12 - Damascus; 13 - Edessa; 14 - Harim; 16 - Harran Hims; 17 - Hisn Akkar; 18 - Hisn al-Akrad; 19 - Hunain; 20 - Jebeleh; 21 - Jerusalem; 22 - Jubail; 23 - Latakiya; 24 - Mardin; 25 - Margat; 26 - Mosul; 27 - Nazareth; 28 - Nisibis; 29 - Qusayr; 30 - Raqqa; 31 - Safita; 32 - Samosata; 33 - Shaizar; 34 - Sinjar; 35 - Sur; 36 - Tayma; 37 - Hama; 38 - Tripolis; 39 Baniyas. 


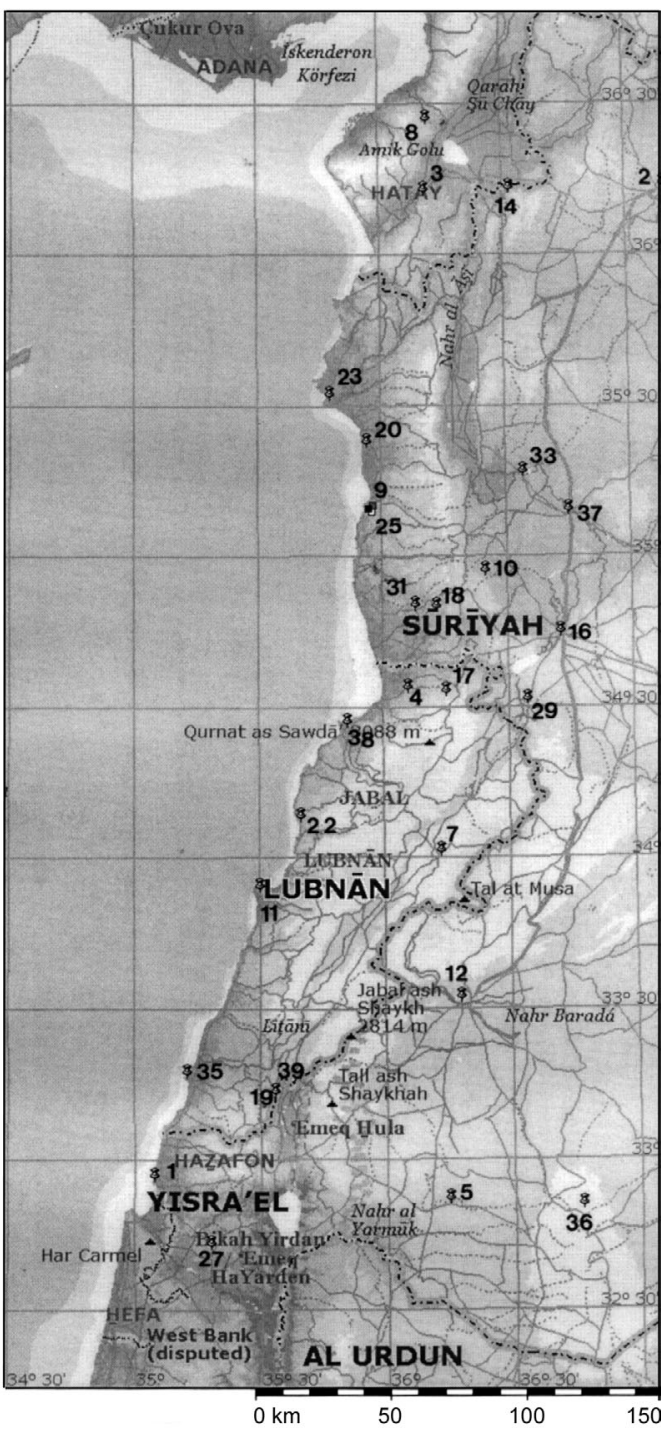

Fig. 6. Location map of the earthquake of 1170.1 Acre; 2 - Aleppo; 3 -Antioch; 4 - Arqa; 5 - Ashtera; 7 - Baalbek; 8 - Baghras; 9 - Bannyas; 10 - Barin; 11 - Beirut; 12 - Damascus; 14 - Harim; 16 - Harran Hims; 17 - Hisn Akkar; 18 - Hisn al-Akrad; 19 Hunain; 20 - Jebeleh; 22 - Jubail; 23 - Latakiya; 25 Margat; 27 - Nazareth; 29 - Qusayr; 31 - Safita; 33 Shaizar; 35 - Sur; 36 - Tayma; 37 - Hama; 38 - Tripolis; 39 - Baniyas. houses with huts (Abu Shama, al-Kauthari, 1947), was again badly damaged (Sibt ibn alJauzi, ed. Chicago 1907) perhaps totally ruined (William of Tyre, RHC Hist. Occid., 1844 and Babcock and Krey, 1943; Kemal al-Din, ROL, 1896 and Röhricht, 1874). There was considerable destruction of its hastily rebuilt walls (Abul Faraj, Bedjan, 1932 and Salhani, 1890) and citadel and many people lost their lives (Ibn alAthir, Cairo 1885; Tornberg, 1853; RHC Hist. Or., 1872; Talimat, 1963). It is said that only one house was left intact (Abu Shama, al-Kauthari, 1947).

Nevertheless, it is likely that what a traveller who passed some years later through the region says, that some 25000 people perished in Hama, and of about 200 Jews but 70 escaped, is not but a gross exaggeration (Ibn Dawadari, alMunajjid, 1960). It may be that he refers to the town and rural areas (Michael the Syrian, Chabot, 1899-1910 and RHC DA, 1869). Again here the walls were quickly repaired (Ibn alAthir, Cairo 1885; Tornberg, 1853; RHC Hist. Or., 1872; Talimat, 1963).

Great parts of the border castle of Barin were destroyed (Kemal al-Din, ROL, 1896 and Röhricht, 1874). Of its citadel not a wall remained standing, and the settlement abutting on Frankish territory was damaged (Ibn al-Athir, Cairo 1885; Tornberg, 1853; RHC Hist. Or., 1872; Talimat, 1963). The repairs occupied the Franks completely for some time (Abu Shama, RHC Hist. Or., 1896).

Also Safitha was almost totally destroyed, and not one wall was left standing (Abu Shama, RHC Hist. Or., 1896). Hisn Akkar was probably shattered (Richard, 1972) but details are lacking. Homs heavily damaged (Sibt ibn alJauzi, ed. Chicago 1907) and great parts of the town were ruined (Kemal al-Din, ROL, 1896 and Röhricht, 1874) causing many victims (Ibn al-Athir, Cairo 1885; Tornberg, 1853; RHC Hist. Or., 1872; Talimat, 1963). Its walls and citadel were shattered, but quickly repaired (Ibn al-Athir, Cairo 1885; Tornberg, 1853; RHC Hist. Or., 1872; Talimat, 1963; Kemal alDin, ROL, 1896 and Röhricht, 1874). Again here the language used by some occidental authors grossly exaggerates damage (William of Tyre, RHC Hist. Occid., 1844; and Babcock 
and Krey, 1943; Michael the Syrian, Chabot, 1899-1910 and RHC DA, 1869). It is said that he castle of Qusayr was also ruined, but details are lacking.

Hisn al-Akrad was seriously damaged, particularly its citadel where, it is said (Sibt ibn alJauzi, ed. Chicago 1907; Abu Shama, RHC Hist. Or., 1896) that its walls were destroyed, which cannot be true (Hagenmeyer, 1890). The Franks rebuilt part of the damage (Abu Shama, RHC Hist. Or., 1896) and the inner enceinte underwent modifications. A massive battered embankment was built up against the wall, which provided resistance against future earthquakes. All we know about Arqa from only one source is that the castle collapsed (Het'un, Hakobyan, 1976 and RHC DA, 1869).

In Baalbek the earthquake caused considerable damage to houses and defenses. Some parts of its wall and citadels were ruined (Kemal alDin, ROL, 1896 and Röhricht, 1874; Abul Faraj, Bedjan, 1932 and Salhani, 1890; Kohl et al., 1925); and a number of people lost their lives (Ibn al-Athir, Cairo 1885; Tornberg, 1853; RHC Hist. Or., 1872; Talimat, 1963). The damage was quickly repaired (Kemal al-Din, ROL, 1896 and Röhricht, 1874). In the mountains overlooking the town, deep fissures opened in the ground (Ibn Dawadari, al-Munajjid, 1960). On one of the gates an inscription commemorates repairs in 1168(?) (Alouf, 1908).

Damage was considerable at Jabalah, Baniyas (Valanin), Margat (Marqab), Tripolis, Jubail, and Damascus. It is said that Jabalah collapsed (William of Tyre, RHC Hist. Occid., 1844 and Babcock and Krey, 1943; Sibt ibn alJauzi, ed. Chicago 1907), however, certain churches are reported as having withstood the shock (Michael the Syrian, Chabot, 1899-1910 and RHC DA, 1869; Abul Faraj, Bedjan, 1932 and Salhani, 1890), and there is no evidence that the earthquake affect this port. The same is said about the castle of Baniyas (Het'un, Hakobyan, 1976 and RHC DA, 1869), information not found in another source. Margat is reported destroyed (Annales 5689: Bibliotèque Nationale de France, Fond Latin 5689). It is mentioned by Röhricht (1874) among the localities damaged or affected by the earthquake, but the name of this locality does not appear in any of the references that he mentions in support (Röhricht, 1898)

A large part of the city of Tripolis was ruined and its castle (Het'un, Hakobyan, 1976 and RHC DA, 1869) and the Great Church collapsed (Michael the Syrian, Chabot, 1899-1910 and RHC DA, 1869) but the town was far from being destroyed as some chroniclers maintain (William of Tyre, RHC Hist. Occid., 1844 and Babcock and Krey, 1943; Robert de Torigni, Delisle, 1872-1873). The Syrian Church and the harbour survived the shock apparently with no serious damage (Michael the Syrian, Chabot, 1899-1910 and RHC DA, 1869). Jubail suffered unspecified damage, serious enough for the Franks to request immediate repairs. Oddly Beirut, is not mentioned in the sources.

In Damascus, one of the large urban centres, the earthquake caused general panic, and in places serious damage to dwellings (Michael the Syrian, Chabot, 1899-1910 and RHC DA, 1869; Ibn al-Athir, Cairo 1885; Tornberg, 1853; RHC Hist. Or., 1872; Talimat, 1963; Kemal alDin, ROL, 1896 and Röhricht, 1874; Robert de Torigni, Delisle, 1872-1873). The inhabitants left the town (Sibt ibn al-Jauzi, ed. Chicago 1907) and made for the plains of Ghuta. Strangely the only damage to public buildings recorded in the urban area is the knocking down of the crenellations of the Great Mosque and the collapse of the roof of the rostrum, and only one man died, hit by a stone (Sibt ibn alJauzi, ed. Chicago 1907). However, damage to the rural district was widespread and serious.

Further away from the epicentral area in Aleppo, the largest urban centre in the region, already shattered by the large earthquake of 1157, damage was widespread and in places serious. The descriptions of damage by Christian and Muslim authors are somewhat coloured by their religious perspective, considering the earthquake to be of divine justice. They grossly exaggerate damage by saying that the whole city of Aleppo collapsed (William of Tyre, RHC Hist. Occid., 1844 and Babcock and Krey, 1943; Michael the Syrian, Chabot, 1899-1910; RHC DA, 1869; Langlois, 1868; Sibt ibn al-Jauzi, ed. Chicago 1907; Abul Faraj, Bedjan, 1932 and Salhani, 1890) becoming a hill of ruins (Michael the Syrian, Chabot, 1899-1910 and RHC DA, 
1869). More sober sources point out that damage was not total. A considerable part of the city (Ibn al-Athir, Cairo 1885; Tornberg, 1853; RHC Hist. Or., 1872; Talimat, 1963) or parts of it were damaged so that the people were not able to take refuge in their homes for fear of another shock (Kemal al-Din, ROL, 1896 and Röhricht, 1874), an observation suggesting that most dwellings survived the shock. And because the shocks had carried on for several days and despite the fact that the people were apprehensive of camping outside Aleppo, lest they found themselves surprised by the Franks (Ibn alAthir, Cairo 1885; Tornberg, 1853; RHC Hist. Or., 1872; Talimat, 1963), they evacuated the city (Ibn al-'Adim, Dahhan, 1951).

There is no doubt that many public buildings, dwellings and some parts of the city walls were damaged, some of them seriously. Half of the citadel was ruined (Sibt ibn al-Jauzi, ed. Chicago 1907), but the Syrian Church suffered absolutely no damage and the Ulu Cami survived with some minor damage to its minaret (Ibn al-Shihnah, British Library, London, Ms Or. Add. 2, 36), the crescent of which was hurled almost $200 \mathrm{~m}$ (Michael the Syrian, Chabot, 1899-1910; RHC DA, 1869; Langlois, 1868; Abul Faraj, Bedjan, 1932 and Salhani, 1890; Ajami Abu Darr, Sauvaget, 1950).

It is said that as a result of the earthquake the ground in the whole city cracked, and was reduced to a series of crevasses and fissures filled with a black fluid (Michael the Syrian, Chabot, 1899-1910; RHC DA, 1869; Langlois, 1868), probably an allusion to liquefaction of the ground along the banks of the Quwayq River.

The death count is suspect with estimates ranging from 5000 (Ibn al-'Adim, Dahhan, 1951) to 80000 (Sibt ibn al-Jauzi, ed. Chicago 1907; al-'Umari, Ms., Iraq Acad., Baghdad). Nevertheless, with Aleppo's jails crowded with several thousand Christian prisoners there is no evidence that any of them lost his life.

Damage was very quickly repaired (Ibn alAthir, Cairo 1885; Tornberg, 1853; RHC Hist. Or., 1872; Talimat, 1963) with the Muslim army camped outside the city supervising the work until they had repaired all of the walls and the principal mosques (Ibn al-Athir, Cairo 1885; Torn- berg, 1853; RHC Hist. Or., 1872; Talimat, 1963; Kemal al-Din, ROL, 1896 and Röhricht, 1874).

It is not certain what happened in Harim. All we know from a Muslim source about Baghras is that its walls «fell down» (Abul Faraj, Bedjan, 1932 and Salhani, 1890).

Antioch on the River Orontes, a large urban centre already badly damaged by the earthquake of 1157, suffered some damage. Some battlements of the city wall on the riverbank were thrown down (Michael the Syrian, Chabot, 1899-1910 and RHC DA, 1869), as well as part of the ramparts (Annales Vizeliacenses, Huigens, 1976) and in places cracks opened in the ground filled with water (Annales Magdeburgenses, Pertz, 1895). The Cathedral Church of St. Peter was shattered and one of the domes fell in Rey (1896), on the Greek patriarch and his clergy, and the altar of the church of St. Cosma caved in (Abul Faraj, Bedjan, 1932 and Salhani, 1890). In contrast, the Syrian Churches St. Mary, St. George and Bar Suma were not damaged (Michael the Syrian, Chabot, 1899-1910 and RHC DA, 1869; Abul Faraj, Bedjan, 1932 and Salhani, 1890). The death toll was relatively low, about 50; most of whom were in the church of St. Peter (Michael the Syrian, Chabot, 1899-1910 and RHC DA, 1869; Neophytus, Delahaye, 1907). The walls of the city and its church were rebuilt (Michael the Syrian, Chabot, 1899-1910; RHC DA, 1869; Langlois, 1868). Internal evidence suggests it is unlikely that Antioch was severely damaged; in fact the earthquake seems to have caused more fear than anything else. Again here, some chroniclers exaggerates the situation, saying briefly that Antioch was completely flattened (William of Tyre, RHC Hist. Occid., 1844 and Babcock and Krey, 1943; Annales Vizeliacenses, Huigens, 1976), overthrown (Michael the Syrian, Langlois, 1868), destroyed (Sibt ibn al-Jauzi, ed. Chicago 1907; Het'un, Hakobyan, 1976 and RHC DA, 1869), or swallowed up in the ground (Annales Magdeburgenses, Pertz, 1895). Others say that parts of the city collapsed (Robert de Torigni, Delisle, 1872-1873; Chronicon universalis Senonensis, Holder-Egger, 1882; Chronicon Gastinensis Coenobii, Rec. Hist. France, 1781), while better-informed sources restrict damage in diverse 
places (Michael the Syrian, Chabot, 1899-1910 and RHC DA, 1869).

There are no records of «destruction» (William of Tyre, RHC Hist. Occid., 1844 and Babcock and Krey, 1943; Sibt ibn al-Jauzi, ed. Chicago 1907) in the coastal towns of Latakia except for its castle that was damaged (Het'un, Hakobyan, 1976 and RHC DA, 1869) but its church was left unscathed (Abul Faraj, Bedjan, 1932 and Salhani, 1890). The fortress of $\mathrm{Hu}-$ nain may have bee damaged, and there is evidence that the wall towers of Sur suffered some unspecified damage (Het'un, Hakobyan, 1976 and RHC DA, 1869), the earthquake causing considerable concern in the port area (William of Tyre, RHC Hist. Occid., 1844 and Babcock and Krey, 1943).

Nothing is known in any detail about Acre except that allegedly its castle collapsed (Het'un, Hakobyan, 1976 and RHC DA, 1869), which is not substantiated by other sources. The earthquake was felt in the region of Nazareth (Anonymous, 1846; Röhricht, 1898), causing some unspecified damage to the Church in Nazareth (Mayer, 1977), and it was perceptible in Jerusalem (Chronicon universalis Senonensis: Holder-Egger, 1882).

There is no evidence that the shock was noticeable at Ashtera (Abu Shama, RHC Hist. Or., 1896; Berchem, 1902) or Cyprus (Neophytus, Delahaye, 1907).

To the east of the epicentral region we know that the walls of Samosata had to be repaired but it is not clear whether this was due to the earthquake (Michael the Syrian, Chabot, 1899-1910 and RHC DA, 1869). Edessa was unscathed, however, the nearby monastery of St. Ananias was shaken to the extent that the clergy clung to the altar (Michael the Syrian, Langlois, 1868; Abul Faraj Bedjan, 1932 and Salhani, 1890). Not only in the monastery but also in the whole country, there had been absolutely no damage (Michael the Syrian, Chabot, 1899-1910 and RHC DA, 1869). The earthquake was felt as far as Raqqa (Sibt ibn al-Jauzi, ed. Chicago 1907), perhaps causing some unspecified damage (Abu Shama, RHC Hist. Or., 1896) and in the region of Mardin, Sinjar, Mosul, and Nisibis (Sibt ibn al-Jauzi, ed. Chicago 1907).
There is nor evidence that the shock was felt in Baghdad, Basra, Harran, and Wasit. These localities are mentioned in the sources merely to indicate the general direction in which the earthquake shaking propagated (Sibt ibn alJauzi, ed. Chicago 1907).

The duration of aftershocks given in the sources vary from a fortnight to four months, but in general there is little hard evidence that aftershocks were either numerous or destructive.

In all, an estimated thirty towns and fortified sites were significantly damaged or destroyed, leaving both the Franks and Muslims open to military attacks from each other. The Franks believed that damage was worse in the Muslim side (Abu Shama, RHC Hist. Or., 1896) and it took them sometime to realise that the earthquake overthrew several cities, as many Christian as Muslim (Annales Colonienses maximi, Pertz, 1861). Thus each side was occupied with repairing the damage, for fear of the other (Kemal al-Din, ROL, 1896 and Röhricht, 1874). Ironically, this resulted in a period of unofficial truce, as both sides were repairing as quickly as possible the fortifications of border citadels. And as after the earthquake of 1157 , repairs were hasty and for many years little proper rebuilding was done. For instance Antioch, although not so badly affected, seems to have suffered from a shortage of funds as, according to a source writing about ten years later, the repairs did not reach «even a mediocre standard».

It is interesting that it was only after the first large shock of 1157 did wood was used extensively in the rebuilding work, which demonstrates that its earthquake-resistant properties took some time before it was appreciated and the cost was partially offset by tax-relief on wood (Abu Shama, al-Kauthari, 1947).

The earthquake was felt in most of the regions of Sham, Jazirah, as far as the borders of Mosul, and in Iraq, while the area of maximum intensity was Syria (Ibn al-Athir, Cairo 1885; Tornberg, 1853; RHC Hist. Or., 1872; Talimat, 1963; Kemal al-Din, ROL, 1896 and Röhricht, 1874), misspelled in some occidental sources as Styria (Annales Admontenses, Wattenbach, 1851), thus placing a spurious large earthquake in Steiermark, in what was then Hungary. This 
error passes on unnoticed to modern writers (Mallet, 1853; Rethly, 1952; Hoernes, 1902).

Undoubtedly the earthquakes of 1157 and 1170 were of sufficient political importance to interest chroniclers throughout Europe.

25 February 1181 - An earthquake caused extensive damage to the city of Aleppo and villages in the surrounding region; the same event may have precipitated rock falls in the mountains. Different manuscripts of al-Suyuti date the event either in 1181 or 1182 .

\section{Acknowledgements}

I would like to thank Jean Vogt for his assistance over the years in systematically locating, but not in the most systematic way recording, valuable information from European repositories. Charles Melville is among those whose help with Arabic texts in the early stages of this work contributed more than he realises. Great help was provided by Dominic White, DO, who patiently read through many Greek and Latin sources during the course of this work. Also, I was fortunate to have comments on this article by two anonymous reviewers that proved particularly helpful.

This articles draws from my previous but now grossly outdated work, sponsored by UNESCO thirty five years ago, and later, in 1996, by the EC BEECD Project. The revision, acquisition of new archival material and publication of these works is aided by the European Commission Project APAME (Archaeo-Palaeoseismology for the Protection of Cultural Heritage and Archaeological Sites in the Middle East), ICA-CT-2002-10024.

\section{REFERENCES}

Journal format restrictions did not allow full pagination of references in the text.

MGH SS = Monumenta Germaniae Historica, Scriptores, Hannoverae, Hahn, 1826-1934, vols.1-32.

PL = Migne J.P., Patrologia Cursus completus..., Series Latina, Parisiis, 1841-1864, vols. 1-221.
RHC DA = Recueil des Historiens des Croisades, Documents Arméniens, Académie des Inscriptions et BelleLettres, Paris 1869-1906, vols. 1-2.

RHC Hist. Occid. = Recueil des Historiens des Croisades, Historiens Occidentaux, Académie des Inscriptions et Belle-Lettres, Paris 1844-1895, vols.1-5.

RHC Hist. Or. = Recueil des Historiens des Croisades, Historiens Orientaux, Académie des Inscriptions et BelleLettres, Paris 1872-1898, vols. 1-5.

RIS 2 = Rerum Italicarum Scriptores...., Nuova edizione, Istituto Storico Italiano per il Medioevo, Città di Castello, ab anno 1900 .

Occidental sources

Annales 5689, Annales de Terre Sainte, Bibliotèque Nationale de France, Paris, Fond Latin, no. 5689, Extr. Archives de 1'Orient Latin, vol. 2.

Annales Admontenses, edited by W. WaTtenBach, MGH SS, vol. 9, Hannover 1851.

Annales Colonienses Maximi, edited by G.H. PERTZ, MHG SS, vol. 17, Hannover 1861

Annales Magdeburgenses, edited by G.H. PerTz, MHG SS vol. 16, Hannover 1895.

Annales Vizeliacenses, edited by R. Huigens, Corpus Christianorum. Continuatio Mediaevalis, 42, Turnholti 1976.

Anonymous, Bibl. de l'Ecole d. Chartres, vol. iv, ser. 3, 1846.

Anselmus Gemblacensis, Sigiberti Gemblacensis chronica Anselmi continuatio, edited by J.P. Migne, PL, vol. 160, Parisiis 1854

BABCOCK, E.A. and A.C. KREY (1943): A history of deeds done beyond the sea by William Archbishop of Tyre, Records of Civilization, 35 (Columbia University Press, New York)

BENJAMIN OF TUdELA, The itinerary of Benjamin of Tudela edited and translated by M.N. ADLER, London 1907.

BENEDICT OF ACCOLTI, Historia Gotefridi, edited by P. RIANT, RHC Hist. Occid., vol. 5, part 2, Paris 1895.

Chronicon Gastinensis Coenobii, Rec. Hist. France, vol. 12, Paris 1781.

Chronicon Universalis Senonensis (quod dicitur Guillelmi Godel), edited by O. HoldER-EGGER, MHG SS, vol. 26. Hannover 1882

Flores Historiarum, edited by H.R. LUARD, Rerum Britannicarum Medii Aevii scriptores, vol. 95, London 1890.

Fulcher, C., Gesta Francorum Hierusalem peregrinantium, RHC Hist. Occid., vol. 3, Paris 1866.

Gesta dei per Francos sive orientalium expeditionum et Regni Francorum Hierosolimitani historia..., Orientalis Historiae, edited by J. BongARs, vol. 1, Hanoviae 1611.

Gesta Francorum et aliorum Hierosolymitanorum, RHC Hist. Occid., vol. 3, Paris 1866.

Matteo Palmieri, Matthei Palmerii liber de temporibus, edited by G. Scaramella, RIS 2, vol. 26/1, Città di Castello 1906-1915.

Neophytus, in P. Delahaye (1907), Saints de Chypre, Analecta Bollandiana, vol. 26.

Robert DE TORIGNI, Chronique de Robert de Torigni, abbé du Mont Saint Michel, suivie de diverses opuscules historiques de cet auteur et de plusieurs religeux de la meme abbaye, edited by L. DELISLE, Société de 1'Histoire de Normandie, Rouen 1872-1873. 
Romoald of SAlerno, Chronicon, edited by C.A. Garufi, RIS 2, vol. 7/1, Città di Castello 1909-1935.

Romoald of Salerno, Chronicon, edited by G.H. Pertz, MGH SS, vol. 19, Hannover 1866.

Sigebertus Gemblacensis, Chronicon, edited by G.H PERTZ, MGH SS, vol. 6, Hannover 1844.

Walter the Chancellor, Bella Antiochena, edited by RIANT, RHC Hist. Occid., vol. 5, Paris 1895.

WILlIAM OF TYRE, Historia rerum in partibus transmarinis gestarum a tempore successorum Mahumeth usque ad a. 1184, cum vet. Trans. Gallica dicta «L'Estoire de Eracles empereur et la conqueste de la terre d'Outremer», RHC Hist. Occid., vol. 1, Paris 1844.

\section{Oriental sources}

ABU 'L-FIDA, Résumé de l'histoire des croisades tiré des Annales d'Abou 'l-Féda, RHC Hist. Or, Paris, vol. 1, 1872.

Aвu Shama, Dhail'ala al-raudatain fi akbar al-daulatayn, edited by M. ZAHID AL-KAUTHARI, Cairo 1947.

AвU Shama, Kitâb al-Raudatayn fi akbar al-daulatayn, edited by M. HiLmI, 2 vols., Cairo 1956-1962.

ABu Shama, Opus dictum Kitâb er-Raudhateïn, sub titulo «Le Livre deux jardins ou Histoire de deux Règnes» auctore Abou Chamach, edited and translated by A.C. BARBIER DE MEYNERD, RHC Hist. Or., vol. 4, Paris 1896.

ABUl FARAJ (Bar Hebraeus) Kitab mukhtasar tawarikh adduwal, edited by A. SALHANI, Beyrouth 1890 .

Abul Faraj (Bar Hebraeus), Chronography, edited by J. BEDJAN and translated by E.W. BUDGE, 2 vols., Oxford 1932.

AJAmi ABu Darr, Sibt ibn al-Ajami, Kunuz al-dhahab fi tarikh Halab, translated by J. SAUVAGET, Materiaux pour servir à l'histoire de la ville d'Alep, Beirut 1950

AL-AINI, Badr al-Din, 'Iqd al-juman fi tarikh al-zaman, Bibliotèque Nationale de France, Paris, Ms. Arabes 5761.

AL-QALQASHANDI, Shihab al-Din, Ma'athir al-Inafa fi mu'alim al-khilafa, edited by A.A. FERRAJ, 2 vols., Kuwait 1964.

AL-SUYUTI, Jalal al-Din, Kashf al-salsala `an wasf al-zalzala, Bibliotèque Nationale de France, Paris, Ms. Ar. 5929.

AL-SUYUTI, Jalal al-Din, Kashf al-salsala 'an wasf al-zalzala, edited by ABD AL-LATIF SA'ADANI, Fez 1971.

AL-TAвBAKH, M., A'lam al-mubala' fi ta'rikh Halab al shahba, vol. 1, Aleppo 1923.

AL-'UMARI YASIN, al-Athar al-jaliyya fi hawadith alardiyya, Ms., Iraq Academy, Baghdad; also British Library, London, Ms. Or. 6300

Chronicon ad annum Christi 1234 pertinens, edited by J.B. Снавот, Corpus Scriptorum Christianorum Orientalium, Scriptores Syrii (CSCO SS), vol. 56 (Ser. III, 15), Louvain 1937.

Gregory the Priest, Chronicle, RHC DA, vol. 1, Paris 1869

HET'Un PATMIČ, Manr Zhamanakagrut'yunner XIII-XVIII $D D$, edited by V.A. HAKOBYAN, Erevan 1976.

Hethoun, Table chronologique de Hethoun, Comte de Gor'igos, RHC DA, vol. 1, Paris 1869.

IBN AL-'ADIM, Zubdat al-halab fi tarikh Halab, edited by S. DAHHAN, Damascus 1951.

IBN AL-ATHIR, al-Kamil fi ' $l$-tarikh, edited by C.J. TORNBERG, vol. 12, Leiden 1853

IBN AL-ATHIR, al-Kamil fi 'l-tarikh, Cairo, Bulaq, 1303/1885,
12 vols. in 6.

IBN AL-ATHIR, al-Tarikh al-bahir fi 'l-daulat al-Atabikiyya, edited by A. TALIMAT, Cairo 1963.

IBN AL-ATHIR, Kamil al-tawarikh, RHC Hist. Or., vol. 1, Paris 1872.

IBN AL-DAWADARI, Kanz al-durar wa jami' al-ghurar, edited by AL-MunAJJID, vol. 7, Cairo 1960.

IBN AL-FURAT, Tarikh al-duwal wa 'l-muluk, vol. iv/1-v, Hassan al-Shamma, Basra 1967.

IBN AL-JAUZI, Abd al-Rahman, Kitab al-muntazam fi tarikh al-muluk wa 'l-uman, Hyderabad 1938-1941.

IBN AL-JAUZI, Abd al-Rahman, Setuth al-iqod fi thiqr alihod, National Library, Cairo, N, M.95.

IBn AL-QALANISI, Dhail tarikh Dimishq, Continuation of the history of Hilal al-Sabi, edited by H.F. AmÉDROZ, History of Damascus 363-555 a.H., Leiden 1908.

IBN AL-QALANISI, The Damascus Chronicle of the Crusades, abr. and translated by H.A.R. GIBB, University of London Historical Series, vol. 5, London 1932, pp. 368.

IBN AL-SHIHNAH, an-Nawadir as-Sultanya, British Library, London, Ms. Or. Add. 2, 36.

IBN KATHIR, al-Bidaya wa 'l-nihaya fi 'l-tarikh, 14 vols., Cairo 1932-1939.

IBN TAGHRIBIRDI, Abu al-Mahasin Yusuf, Al-Nujum 'al-zahirah fi muluk Misr wa-'al-Qahirah, edited by F.M. SHaltuT et al., 16 vols., Cairo 1929-1972.

IBN WASIL, Mufarrij al-kurub fi akhbar Bani Ayyub, edited by M. SHAYYAL, vol. 3, Cairo 1962.

Kemal aL-Din, Die Sahne der Geschichte Halebs, edited by R. RÖHRICHT, part 3, 1874.

Kemal AL-Din, Extraits de la Chronique d'Alep par Kémal ad-Din, RHC Hist. Or., vol. 3, Paris 1884

Kemal AL-Din, Zubdat al-halab-min tarikh Halab, ROL (Revue de l'Orient Latin), vol. 3, 1896.

MatThew of Edessa, Chronicle, translated by E. DulauriER, RHC DA, vol. 1, Paris 1869.

Michael the Syrian, Chronique de Michel le Grand patriarche des Syriens Jacobites, translated by V. LANGLOIS, Académie de Saint-Lazare, Venise 1868, 378 pp.

Michael the Syrian, Chronique de Michel le Syrien, patriarche jacobite d'Antioche (1166-1199), edited and translated by J.-B. CHABот, 4 vols., Paris 1899-1910.

MichaEl THE SyRIAN, Fragmentum chronici, RHC DA, vol. 1, Paris 1869.

Nicetas Choniates Acominatus, Historia, edited by J. BEKKER, Corpus Scriptorum Historiae Byzantinae, vol. 33, Bonn 1835

Sembat, Chronique de la Petite Armenie, RHC DA, vol. 1, Paris 1869.

SibT IBN AL-JAUZI, Shams al-Din, Mir'at al-Zaman (facs edition), Chicago 1907

UsAMA IBN MUNOIDH, Kitab al-manazil wa'l-diyar, edited and translated by P.K. HitTI, London 1987.

YAQUT AL-HAMAWI, Mu`jam al-buldan, edited by F. WÜSTENFELD, 4 vols, Leipzig 1866-1873.

Other works

AleXANDRE, P. (1990): Les séismes en Europe occidentale de 394 à 1259. Nouveau catalogue critique, Ser. Géophys., Observ. R. de Belgique (Bruxelles), pp. 267.

ALOUF, M.M. (1908): History' of Baalbek (Beirouth). 
Ambraseys, N.N. (1989): Temporary seismic quiescence: SE Turkey, Geophys. J. Int., 96, 311-331.

AMBRASEYS, N.N. (1997): The earthquake of 1 January 1837 in southern Lebanon and northern Israel, Ann. Geofis., XL (4), 923-935.

AMBRASEYS, N.N. (2001): Far-field effects of Eastern Mediterranean earthquakes in Lower Egypt, J. Seismol., 5, 263-2001

Ambraseys, N.N. and M. BARAZANGI (1989): The 1759 earthquake in the Bekaa Valley, J. Geophys. Res., 94, 4007-4013.

Ambraseys, N.N. and R. BiLham (2003): Reevaluated intensities for the Great Assam earthquake of 12 June 1897, Bull. Seismol. Soc. Am., 93, 655-673.

AmBrasEYs, N.N. and J.A. JACKSON (1998): Faulting associated with historical and recent earthquakes in the eastern Mediterranean region, Geophys. J. Int., 133 (2), 390-406

Ambraseys, N.N. and C.P. Melville (1988): An analysis of the eastern Mediterranean earthquake of 20 May 1202, in Historical Seismograms and Earthquakes of the World, edited by W.H.K. LEE, H. MEYERS and K. SHIMAZAKI (Acad. Press, San Diego, CA, U.S.A.), 181-200.

AmbraseYs, N.N., J.A. JACKSON and C.P. Melville (2004): The Historical Seismicity of the Eastern Mediteranean and of the Middle East (Imperial College Press), vol. 2 (forthcoming).

BARKAN, Ö.L. (1958): Essai sur les données statistiques des registres de recensement dans l'Empire Ottoman aux 15 et 16 siècles, J. Econ. Soc. Hist. Orient (Leiden), 1, p. 25.

Ben-MenAhem, A. (1979): Earthquake catalogue for the Middle East (92 B.C.-1980 A.D.), Boll. Geofis. Teor. Appl., 21 (84), 245-310.

BERCHEM, M. van (1902): Notes sur les Croisades; le Royaume de Jerusalem et le livre de M. Röhricht, J. Asiat., May, 385-456.

Berchem, M. van and E. Fatio (1913): Voyage en Syrie, Mém. Inst. Français d'Archéol. Orient. du Caire (Le Caire), vols. 37-38.

CAhen, C. (1940): La Syrie du nord a l'époque des croisades et la principauté franque d'Antioche, Bibl. Orientale (Institut Français de Damas, Paris), vol. 1.

Cattenoz, H.G. (1961): Tables de concordance des éres chrétienne et hégirienne (Rabat).

Deschamps, P. (1935): Le chateau de Saone et ses premiers seigneurs, Syria, vol. 16.

Dulaurier, E. (1861): Etude du royaume de la Petit-Arménie. J. Asiat., Ser. 5, 17, 435-436.

Dussaud, R. (1927): Topographie historique de la Syrie antique et médiévale (P. Gauthner, Paris).

ElissEEF, N. (1951): Les monuments de Nur ad-Din, Bull. d'Etudes Orientales (Institut Français de Damas, Paris), vol. 13.

ELISSEEFF, N. (1967): Nur ad-Din. Un grand prince musulman de Syrie au temps des croisades (Institut Français de Damas, Damas), 511-569 H., 1118-1174, 3 vols.
ENLART, C. (1925): Les monuments des Croisés dans le royaume de Jerusalem, Bibliothèque Archéologique et Historique, Paris, vol. 1.

Grumel, V. (1958): Traité d'études Byzantines I, La chronologie (Paris).

GuYARD, S. (1877): Un grand maître des Assassins au temps de Saladin, J. Asiat., Ser. 7, 9, p. 413

Hagenmeyer, H. (1890): Anonymi Gesta Francorum et aliorum Hierosolymitanorum (Heidelberg).

HöRNES, R. (1902): Erdbeben und Stosslinien Steiermarks. Mitteilungen der Erdbeben-Kommission der Kaiserlichen Akademie der Wissenschaften in Wien (Neue Folge), VII, 1-115.

KoHl, H., D. KRENKer et al. (1925): Baalbek (Walter de Gruyter, Berlin), iii. 8.

Kremer, A. (1880): Über die grossen Seuchen des Orients nach arabischen Quellen, Zitzugsber, K. Akad. Wissen. Philos. Hist. Classe, 96 (2), 69-156.

MaAlouf, A. (1983): Les croisades vues par les Arabes (J. Lattès, Paris).

MALLET, R. (1853): Catalogue of recorded Earthquakes from 1606 B.C. to A.D. 1850 , Brit. Ass. Rep., 1853, 1-176.

MAYER, H.E. (1977): Bistümer, Klöster und Stifte im Königreich Jerusalem, edited by A. HIERSEMANN (Stuttgart), p. 338.

POIRIER, J.P. and M.A. TAHER (1980): Historical seismicity in the Near and Middle East century, North Africa, and Spain from Arabic documents (7th-18th century), Bull. Seismol. Soc. Am., 70 (6), 2185-2201.

Rethly, A. (1952): A Kárpátmedencék földrengési (Akadem. Kiadó, Budapest), p. 24.

REY, E. (1896): Resumé chronologique de l'histoire des Princes de l'Antioche, Rev. Orient Latin, 4, 321-407.

REY, E. (1901): Les dignitaries de la principauté d'Antioche, Rev. Orient Latin, 8, 123-128.

RichaRD, J. (1972): Le comté de Tripoli dans les chartes de fonds des Porcellet, Bibl. de l'Ecole des Chartes, vol. 130.

RÖHRICHT, R. (1898): Geschichte des Königreichs Jerusalem (Innsbruck), pp. 1105.

RuncIMAN, R. (1951-1952-1954): A history of the crusades (Cambridge Univ. Press).

SiEBERG, A. (1932a): Die Erdbeben, in Handbuch der Geophysik, edited by B. GuTENBERG (Berlin), vol. IV, 90-126.

SIEBERG, A. (1932b): Untersuchungen über Erdbeben und Bruchschollenbau im Östlichen Mittelmeergebeit, Denkschr. Medizin.-Natürwiss. Ges., Jena, 18 (2), 161-273.

TAHER, M.A. (1979): Corpus des textes arabes relatifs aux tremblements de terre, Doctoral Thesis (Sorbonne, Paris), 2 vols.

TAHER, M.A. (1996): Les grandes zones sismiques du monde Musulman à travers l'histoire, Annales Islamologiques (Inst. Français d'Archaeol. Orient. du Caire), vol. 30, 79-104.

WILLIS, B. (1928): Earthquakes in the Holy Land, Bull. Seismol. Soc. Am., 18, 73-103.

WILLIS, B. (1933): Earthquakes in the Holy Land, a correction, Science, 77 (1997), 88-89. 